\title{
The critical roles of activated stellate cells- mediated paracrine signaling, metabolism and onco-immunology in pancreatic ductal adenocarcinoma
}

Yaojie Fu ${ }^{1,2}$, Shanshan Liu ${ }^{1,2}$, Shan Zeng ${ }^{1,2,3}$ and Hong Shen ${ }^{1,2,3^{*}}$

\begin{abstract}
Pancreatic ductal adenocarcinoma (PDAC) is one of the most lethal malignant diseases worldwide. It is refractory to conventional treatments, and consequently has a documented 5-year survival rate as low as 7\%. Increasing evidence indicates that activated pancreatic stellate cells (PSCs), one of the stromal components in tumor microenvironment (TME), play a crucial part in the desmoplasia, carcinogenesis, aggressiveness, metastasis associated with PDAC. Despite the current understanding of PSCs as a "partner in crime" to PDAC, detailed regulatory roles of PSCs and related microenvironment remain obscure. In addition to multiple paracrine signaling pathways, recent research has confirmed that PSCs-mediated tumor microenvironment may influence behaviors of PDAC via diverse mechanisms, such as rewiring metabolic networks, suppressing immune responses. These new activities are closely linked with treatment and prognosis of PDAC. In this review, we discuss the recent advances regarding new functions of activated PSCS, including PSCs-cancer cells interaction, mechanisms involved in immunosuppressive regulation, and metabolic reprogramming. It's clear that these updated experimental or clinical studies of PSCs may provide a promising approach for PDAC treatment in the near future.
\end{abstract}

Keywords: Pancreatic stellate cells, PDAC, Metabolic reprogramming, Immune evasion, Drug resistance

\section{Background}

Pancreatic ductal adenocarcinoma (PDAC) is an aggressive cancer, which is characterized by rapid progression, early metastasis, high recurrence, poor prognosis and limited responsiveness to conventional therapies [1,2]. Worldwide, PDAC is becoming increasingly common, and has a 5-year survival rate of only 7\% [3]. Despite numerous methods in PDAC treatment, including new chemotherapeutic agents, emerging immunotherapy, and advanced surgical skills, the long-term survival rate has not shown significant improvement over the past decade. There are few effective therapeutics that can extend the overall survival of patients with PDAC [4].

\footnotetext{
* Correspondence: hongshen2000@csu.edu.cn

'Department of Oncology, Xiangya Hospital, Central South University, Changsha, Hunan 410008, China

${ }^{2}$ Institute of Medical Sciences, Xiangya Hospital, Central South University,

Changsha, Hunan 410008, China

Full list of author information is available at the end of the article
}

In recent years, it's commonly recognized that pancreatic tumor microenvironment (TME) plays a pivotal role in PDAC carcinogenesis, progression and therapeutic resistance [5]. As a key orchestrator of TME, pancreatic stellate cells (PSCs) aroused considerable attention for its potential value in PDAC therapeutics [6]. In TME, the dynamic interactions between cancer cells and PSCs critically manipulate PDAC behaviors via diverse mechanisms.

The field of PSCs research emerged at the end of 20th century. It has been well established that PSCs are responsible for producing the desmoplastic reaction (fibrosis) of PDAC [6-8]. In addition, with exponentially increasing experimental data, more details regarding biology and functions of PSCs are coming to light $[8,9]$. In particular, recent evidence indicated that PSCs exert multiple functions in paracrine actions, metabolic rewiring and intricate immune responses in PDAC.

Undoubtedly, further explorations on molecular regulatory mechanisms, PSCs-cancer cells interactions, and 
the clinical value of PSCs may benefit patients with PDAC. Targeting PSCs within the TME as a means of inhibiting PDAC progression is an attractive idea, which may revolutionize PDAC patient treatment and outcome [10].

\section{Phenotypic and functional transition of PSCs}

Pancreatic stellate cells (PSCs), a periacinar star-shaped stromal cell type in healthy pancreas, were successfully isolated and cultured in 1998 [11, 12]. PSCs share many characteristics with hepatic stellate cells, including morphology, storage of lipid droplets rich in vitamin A, locations, and marker protein expressions $[13,14]$. Under homeostatic conditions, quiescent pancreatic stellate cells (qPSCs) localize in basolateral aspects of acinar cells, or surround perivascular and periductal regions. qPSCs are capable of expressing several protein markers, such as glial fibrillary acidic protein (GFAP), synemin, and desmin, most of which are not specific $[15,16]$. Even though the physiological roles of qPSCs haven't been fully delineated, some functions are postulated and widely recognized. These functions include retinoid storage, basic exo-/endocrine secretion, maintenance of pancreatic tissue architecture, stimulation of amylase secretion, phagocytosis, and immunity [16] (Table 1). In general, qPSCs are believed to contribute to the normal status of the pancreas $[15,16]$.

During PDAC, resident qPSCs are activated by some risk factors (e.g. ethanol and its metabolites, chronic inflammation, smoking), environmental stress (e.g. hypoperfusion, hypoxia, oxidative stress), cellular factors (e.g. IL-1, IL-6, HIF1 $\alpha$, TGF- $\beta$, CCN2) and molecular regulating pathways (e.g. Wnt/ $\beta$-catenin signaling, PI3K pathway), and then transform into an activated myofibroblast-like phenotype [17-19]. Activated PSCs (aPSCs) lose cytoplastic lipid droplets, and express fibroblast activation proteins, such as $\alpha$-smooth muscle actin ( $\alpha$-SMA), and fibroblast activation protein- $\alpha$ (FAP- $\alpha)$, which serve as biomarkers for aPSCs identification and are negative prognostic factors in PDAC [17-19]. Meanwhile, aPSCs are the most important cellular source of cancerassociated fibroblasts (CAFs). As a key component in PDAC stroma, CAFs have high-level heterogeneity, the distinct subpopulations show complicated effects on growth and progression of PDAC [20, 21]. Moreover, it's been verified that CAFs derive from diverse cellular origins, including bone marrow-derived cells (BMDCs), epithelium, and resident fibroblasts. Actually, CAFs and aPSCs are different stromal cell populations in PDAC. Even though both of CAFs and aPSCs share some common markers, none of these biomarkers are specific $[20,21]$. The differences between the CAFs and aPSCs are still under debate.

aPSCs also acquire proliferative capacity, and induce desmoplastic response via synthesizing abundant extracellular matrix (ECM) $[19,22,23]$. The desmoplastic reaction is widely regarded as a hallmark of PDAC, more importantly, it's shown to be predominantly responsible for intercellular signaling and TME reprogramming [23] (Fig. 1). However, the contribution of TME-associated desmoplasia to PDAC growth and progression is still obscure and controversial. The 'stiff' stroma impairs the drug delivery, some investigations indicated that depletion of tumor-associated stroma in mouse PDAC models by using enzymatic degradation of hyaluronic acid (HA) or Sonic Hedgehog inhibitor IPI926 could suppress

Table 1 Biological comparison of quiescent PSCs (qPSCs) and activated PSCs (aPSCs)

\begin{tabular}{|c|c|c|}
\hline & Biological behaviors or functions & Specific/selective biomarkers \\
\hline qPSCs & $\begin{array}{l}\text {-Store retinoids in droplets }[13,17] \\
\text {-Function as an immune, progenitor and intermediary cell [16] } \\
\text {-Stimulate amylase secretion, phagocytosis and immunity [16] } \\
\text {-Secrete MMPs and TIMPs to maintain ECM turnover; prevent collagens deposition [17] } \\
\text {-Produce cytokines, growth factors; basic exo/endocrine secretions in a proper way [18] } \\
\text {-May contribute to acinar regeneration [18] } \\
\text {-Involve in maintenance of pancreatic tissue architecture }[16,18] \\
\text {-Help to sustain homeostasis in pancreas microenvironment [16] }\end{array}$ & $\begin{array}{l}\text { desmin }[15,16] \\
\text { nestin }[15,16] \\
\text { vimentin }[18] \\
\text { synemin }[15,16] \\
\text { GFAP }[15,16] \\
\text { NGF }[15,16]\end{array}$ \\
\hline aPSCs & $\begin{array}{l}\text {-Induce desmoplastic reactions in TME [19], elevate interstitial pressure [22] } \\
\text {-Induce hypovascularity and produce excess ECM [19,23] } \\
\text {-Contribute to hypoxic and low-nutrient conditions }[77,79] \\
\text {-Lose vitamin A lipid vacuoles [18] } \\
\text {-Develop spindle-shaped morphology }[17,18] \\
\text {-Generate growth factors (GFs), cytokines, exosomes, micRNAs that enhance tumor survival, } \\
\text { proliferation, migration and metastasis }[34,73,84,85] \\
\text {-Promote angiogenesis, PNI and EMT }[44,45,54,61] \\
\text {-Mediate chemoresistance and radioresistance }[70,105] \\
\text {-Contribute to complex metabolic networks in TME [112, 115] } \\
\text {-Interact with PDA cells or other stromal components [47] } \\
\text {-Contribute to immunosuppressive regulations and immune evasion [130-133] }\end{array}$ & $\begin{array}{l}\text { a-SMA }[17,18] \\
\text { FAP-a }[19] \\
\text { FSP-1 }[17-19] \\
\text { Fibrinogen }[18,19]\end{array}$ \\
\hline
\end{tabular}

Notes: Biological behaviors and functions dramatically change during phenotypic transition of PSCs. Biomarkers of qPSCs are not specific.

Abbreviations: aPSCs activated pancreatic stellate cells, qPSCs quiescent pancreatic stellate cells, GFs growth factors, PNI perineural invasion, EMT EpithelialMesenchymal Transition, TME tumor microenvironment, GFAP glial fibrillary acidic protein, $\alpha$-SMA a-smooth muscle actin, NGF nerve growth factor, FAP- $\alpha$ fibroblast activation protein-a, FSP-1 fibroblast-specific protein-1 


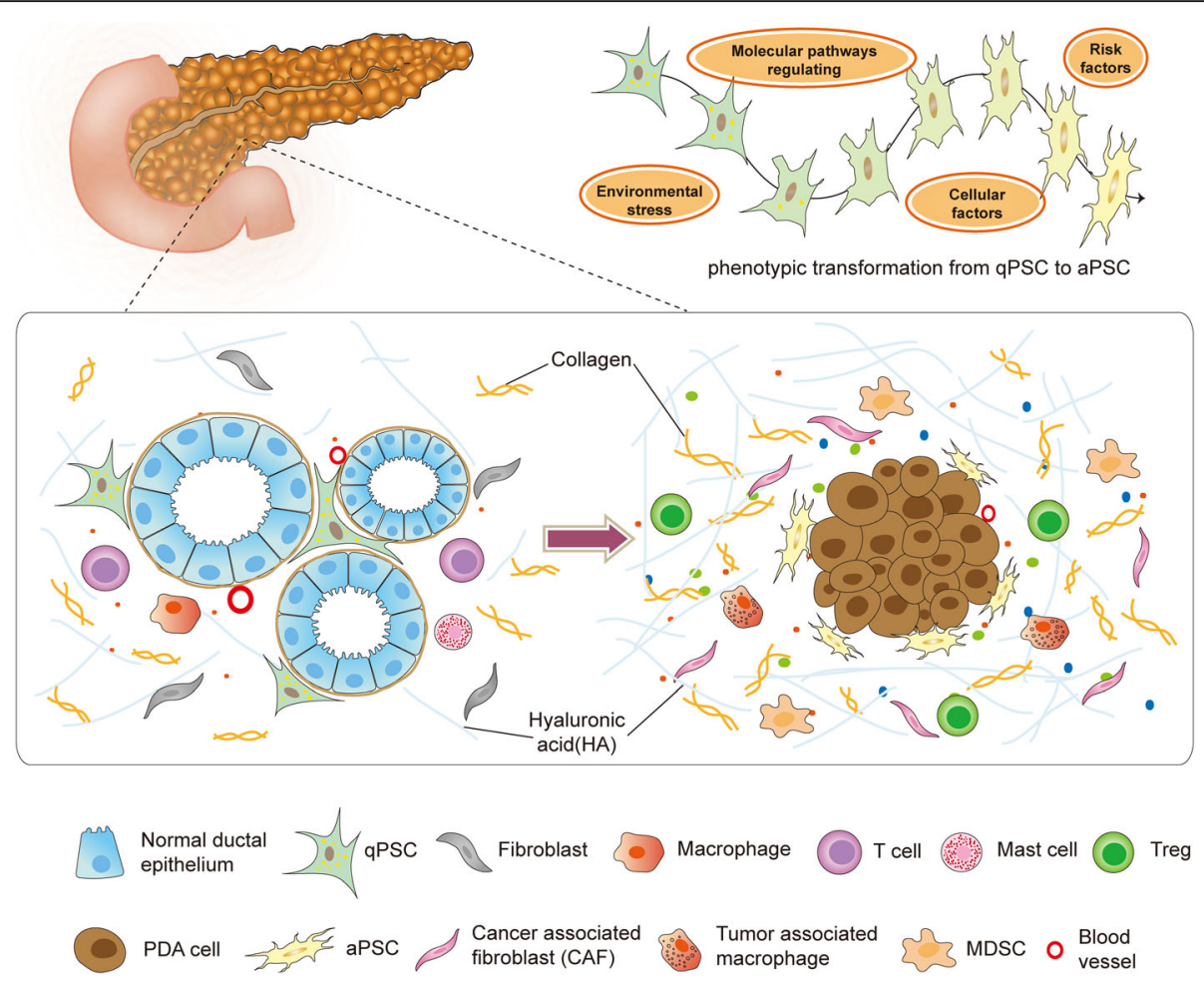

Fig. 1 Phenotypic transition of PSCs and desmoplastic TME. qPSCs are activated by risk factors, local environmental stress, cellular and molecular regulations. During the oncogenesis, aPSCs largely contribute to fibrotic microenvironment, which is a major characteristic of PDAC. The desmoplastic TME consists of epithelial PDA cells and numerous stromal components, such as immunosuppressive cells, aPSCs, collagens and so on

PDAC progression [24, 25]. Oppositely, some new preclinical and clinical data suggested that stromal desmoplasia acts to restrain, rather than support PDAC progression [26]. Depletion of myofibroblast and collagen in PDAC displays immunosuppression, enhanced tumor hypoxia, EMT program and cancer stem cell-like phenotype [27]. Activation of Rho-associated protein kinase2 (ROCK2) signaling can promote PDA cells proliferation and invasiveness via matrix metalloproteinases (MMPs) release and collagen degradation [28]. Clinically, high stromal density in resected PDAC was found to be significantly associated with longer disease-free [29]. Taken together, the TME-associated desmoplasia, representing aPSCs activity, plays a dual role in PDAC. Further exploration of desmoplastic reaction is really necessary.

Additionally, persistent PSCs activation results in dramatically increased secretion of a wide variety of cytokines, chemokines, growth factors (GFs), and exosomes, which perform various pathological functions of PDAC. aPSCs-derived insulin-like growth factor 1 (IGF1), vascular endothelial growth factor (VEGF) and platelet-derived growth factor (PDGF) may promote angiogenesis, epithelial cancer cells proliferation and migration [16, 30, 31]. The overproduced matrix such as collagens, hyaluronic acid (HA) and unbalanced expression of matrix metalloproteinase and its inhibitors (MMPs, TIMPs), cause sustained fibrosis and create a physical barrier to nutrients or therapies [32,33]. Recently, more studies suggested that aPSCs play a reciprocal role in the stroma-cancer cells interactions, which support PDAC malignant behaviors via inducing drug resistance, metabolic rewiring, and immune evasion [33, 34].

Collectively, in contrast to qPSCs, aPSCs are morphologically and functionally transformed. The activated phenotype can accelerate TME formation, and frequently promote PDAC progression through diverse pathways [35] (Table 1).

\section{PSCs related diverse paracrine and molecular pathways that influence invasion, metastasis, and therapeutic resistance of PDAC}

PSCs are an important source of secretions in TME [7, 36]. A large number of GFs, chemokines, cytokines, miRNAs, exosomes and other soluble substances secreted by PSCs, act in an autocrine or paracrine manner to orchestrate continued PSCs activation and signaling transfer between stroma and epithelial cancer cells [37-39].

(1) IL-6/JAK/STAT signaling: The presence of chronic inflammation is a hallmark of PDAC progression [40]. Recent evidence implicated that PSCs is a main source for large amounts of inflammatory signals. Interleukin- 
6 (IL-6), a cytokine that is produced in abundance by components of stroma including PSCs and tumorassociated myeloid cells [41-43], can exert versatile functions to promote PDAC progression. In particular, IL-6 in TME can activate downstream JAK/STAT signaling via the transmembrane receptor gp130. It's evidenced that IL-6/JAK/STAT signaling axis in TME plays an important role in the transformation from pancreatic intraepithelial neoplasia (PanIN) to carcinoma [44, 45], PDAC aggression, TME remodeling and therapeutic resistance $[41,46]$. IL-6/STAT axis activated by aPSCs significantly upregulates some genes expression in PDA cells, such as major EMT regulator Snail, mesenchymal marker $C D H 2$, and invasion related genes $C C L 20, C F B, L C N 2$ etc, which correlates PDAC migration and evolution [42, 47]. Suppressor of cytokine signaling 3 (SOCS3) serves as a potently negative regulator that inhibits PDA cells migration, invasion, and enhances PDA cells apoptosis. Recent study demonstrated that IL-6/ STAT3 axis could induce SOCS3 methylation via DNMT1, which leads to PDAC growth and metastasis [48]. Moreover, PSCs-secreted IL-6 could not only induce PDA cells proliferation via nuclear factor erythroid 2 (Nrf2)-mediated metabolic reprogramming and reactive oxygen species (ROS) detoxification [48], IL-6/STAT/Nrf2 pathway was also implied to promote EMT in PDAC [47].

Additionally, recent findings suggested the IL-6/JAK/ STAT3 axis promotes the recruitment of immunosuppressive cells (e.g. MDSCs, Tregs), which hampers immune responses of PDAC [49].

In general, paracrine IL-6/JAK/STAT signaling plays a pivotal role in PSCs-PDA cells interaction and PDAC progression. Pharmacologic blockade of IL-6/JAK/STAT signaling may be a new therapeutic strategy for patients with PDAC.

(2) Paracrine Sonic Hedgehog (SHH) signaling: Current study shows paracrine sonic hedgehog (SHH) signaling, which involves both epithelial cancer cells and stromal cells, promotes cancer cells-stroma interactions and ultimately contributes to PDAC progression [50]. To date, it's clear that paracrine SHH protein, which is secreted by PDA cells, serves as a hedgehog $(\mathrm{HH})$ pathway ligand. SHH signaling is mediated by $\mathrm{HH}$ ligand binding to the membrane-localized receptor patched (PTCH) on PSCs, which relieves the inhibitory effect on a Smoothened (SMO) receptor. Derepressed SMO then leads to a cascade of cytoplasmic events in PSCs that facilitates the activation of GLI family zinc finger transcription factors, modulating targeted genes expression and eventually resulting in PSCs activation [51-55]. In turn, it's increasingly apparent that aPSCs regulate TME remodeling and promote malignant behaviors of PDAC, including driving desmoplastic stroma [52], increased vascularity [26], uncontrolled proliferation [53, 55], perineural invasion (PNI) [54], and drug resistance [5355]. Despite the prevailing notion, that hedgehog-driven stroma plays a critical role in neoplastic growth and $\mathrm{PDAC}$ progression. Inhibition of SHH signaling seems to enhance delivery of chemotherapy and improve the outcomes of PDAC [24]. However, some current data provided more uncertainties of this opinion, and even shifted to the opposite paradigm that $\mathrm{SHH}$ signaling may partially act to restrain PDAC growth [26]. The studies demonstrated that in spite of the success of IPI926 in treating PDAC mouse models, treatment with SMO inhibitors alone in PDAC trials showed poor clinical performance [24]. In contrast, the administration of vascular endothelial growth factor receptor (VEGFR) blocking antibody selectively improved survival of SHH-deficient PDAC, which suggested that $\mathrm{SHH}$ signaling-driven stroma may suppress PDAC growth partly by restraining tumor angiogenesis [26]. Generally speaking, $\mathrm{SHH}$ signaling exerts complicated functions in PDAC. More details need to be elucidated in the future.

(3) Vitamin D Receptor (VDR) pathway: Wide prospective studies have demonstrated that there is a defined inverse correlation between circulating levels of Vitamin D and risk of developing PDAC or other malignancies [56]. aPSCs express high levels of the VDR. As a notably alternative pathway, Vitamin D Receptor (VDR) signaling plays a critical role in driving conversion of qPSCs to their activated state, which then results in stromal remodeling of PDAC [57, 58]. Further investigations shows after treated with Vitamin D analogue Paricalcitol, PSCs activation can be partly reverted $[16,58]$. It reveals that PSCs related VDR pathway may serve as a promising molecular target in PDAC therapy [56-58].

(4) CXCL12/CXCR4 signaling axis: PSCs is a predominant source of $\mathrm{C}-\mathrm{X}-\mathrm{C}$ motif chemokine 12 (CXCL12) in TME [59]. High-mobility group box 1 (HMGB1) secreted by stressed PDA cells can capture CXCL12 and then form a heterocomplex. It's evidenced that HMGB1CXCL12 complex interacts with C-X-C chemokine receptor type 4 (CXCR4), which is highly expressed in PDA cells under hypoxic conditions (or HIF- $1 \alpha$ expressed strongly) [59]. The HMGB1-CXCL12 complex can induce a range of downstream aggressive behaviors, including: (1) gemcitabine treatment resistance [60]; (2) promoting proliferation, EMT, angiogenesis and metastasis of PDA cells [61]; (3) elevating MMP2,9 expression, cancer cells invasion and migration [60-62]; (4) activating other pathways, such as PI3K/Akt signaling, Ras/ERK pathway [63]; and (5) blunting immunotherapeutic efficacy, inducing immunosuppressive status [64].

(5) Other representative paracrine signaling pathways: Apart from mentioned above, various paracrine components or intercellular signaling are involved in PSCs activation and PSCs (or CAFs)-cancer cells 
Table 2 PSCs mainly involved paracrine pathways and their functions

\begin{tabular}{|c|c|c|c|}
\hline Paracrine signaling & Mediator(s) & Description & Functional roles \\
\hline $\begin{array}{l}\text { Toll-like receptor (TLR) } \\
\text { signaling }\end{array}$ & DAMPs in TME & $\begin{array}{l}\text { TLR9 is activated both in PDA cells and } \\
\text { PSCs }\end{array}$ & $\begin{array}{l}\text { Pro-inflammatory effects [82] } \\
\text { Up-regulated expression of PSCs-derived cytokines } \\
\text { (e.g. CCL3, CCL11) [83] } \\
\text { Recruitment of } \mathrm{T}_{\text {reg }} \text { cells in PDAC [83] }\end{array}$ \\
\hline $\begin{array}{l}\text { IL-6/JAK/STAT } \\
\text { signaling }\end{array}$ & $\| \mathrm{L}-6$ & $\begin{array}{l}\text { A versatile pathway in PSCs-PDA cells } \\
\text { interactions }\end{array}$ & $\begin{array}{l}\text { Inducing chemoresistance, fibrotic reaction }[44,46] \\
\text { Invasive TME remodeling [47] } \\
\text {.Affecting other cytokines production } \\
\text {.Recruitment of immunosuppressive cells [49] } \\
\text {.Enhancing tumor aggressiveness via PSCs-PDA cells } \\
\text { crosstalk }[44,47]\end{array}$ \\
\hline
\end{tabular}

$\begin{array}{lll}\text { Shh signaling } & \text { SHH protein } & \text { An altered signaling between PSCS }\end{array}$ and tumor cells

\section{CXCL12 (SDF-1) CXCR4 signaling \\ PSCs-derived SDF-1 (CXCL12)}

MCP-1/CCR2 pathway MCP-1 expressed in PSCs

Ets-2-dependent regulation

Peroxisome proliferator activated receptor- $\gamma$ signaling (PPAR- $\gamma$ )

Periostin pathway periostin

E26 oncogene homolog 2 (Ets-2) originated in PSCs

PPAR- $\gamma$ ligands characterized as the master regulator

A secretory protein mainly from PSCs, whose expression regulates behaviors

Various miRNAs and exosomes derived from PDA aspects of TME remodeling, PSCscells or PSCs

kindlin-2

$\beta$-galactoside-binding protein expressed in activated PSCs
A nuclear hormone receptor that is for adiopogenic properties in PSCs of both PSCs and TME

A recent hot spot, covering many

An important cytokine signaling mediating PSCs activation and fibrogenic ECM

New functions unlocked about Est-2 signaling in TME of PDAC

tumor cells interactions

Newly identified signaling

A heterotrimer protein strongly expressed in the stroma of PDAC
-Sustaining PSCs activation and proliferation [51-55]

.Promoting vasculature and desmoplasia [52]

Driving perineural invasion (PNI) and drug resistance [53-55]

.Tumor proliferation and progression [51, 53]

Causing low response to gemcitabine treatment [60] Promoting PDAC progression via enhanced proliferation, EMT, angiogenesis and metastasis [61] -Inducing over-expressed MMPs, up-regulated invasiveness and migration of tumor cells $[60,62]$ -Supporting immunosuppressive environment [64] -A potential target for PDAC immunotherapy combined with CTLA-4 or PD-L1 checkpoint block [64]

Serving as a novel component in PSC inflammatory and fibrogenic signaling [81]

Mediating monocytes migration into pancreases and then differentiation into PSCs [81]

Maintaining activated status of PSCs through autocrine manner [15]

Stromal Ets-2 regulates chemokines production and immune cells recruitment during PDAC

Fibroblast Ets-2 deletion leads to an increased CD8

+T-cell population, and decreased presence of regulatory T cells (Tregs), MDSCs [74]

Maintenance of quiescent status of PSCs $[15,65]$ .PPAR- $y$ ligand may enhance the phagocytic activity of PSCs, which is partially responsible for the inhibition of fibrogenesis [66]

Periostin secreted by PSCs creates a tumor-supportive microenvironment [67]

.PSCs remains via periostin autocrine loop [68] Biphasic effects on PDAC development: low concentration of periostin (to $150 \mathrm{ng} / \mathrm{ml}$ ) drives mesenchymal-to-epithelial phenotypical transition while high concentration $(1 \mu \mathrm{g} / \mathrm{ml})$ promoting cancer cell migration via Akt/PKB signaling pathway [69]

Controlling myofibroblast phenotype of PSCs [84] Promoting migration and proliferation of tumor cells $[85,87]$

-Mediating metabolic reprogramming, TME remodeling and intracellular interplay [86] -Delivering nutrients for cancer cells [84]

Binding of kindlin-2 and integrin, promotes cytokines production in PSCs and further accelerating progression of pancreatic cancer [39]

Promoting proliferation and chemokine synthesis of activated PSCs [70]

Contributing to the immune escape by enhanced apoptosis and anergy of T cells [71, 72] Inducing SDF-1 secreted from PSCs; promoting PDAC metastasis [71, 72] 
Table 2 PSCs mainly involved paracrine pathways and their functions (Continued)

\begin{tabular}{|c|c|c|c|}
\hline Paracrine signaling & Mediator(s) & Description & Functional roles \\
\hline $\begin{array}{l}\text { Vitamin D Receptor } \\
\text { (VDR) pathway }\end{array}$ & Circulating Vitamin D & $\begin{array}{l}\text { A promising target for PDAC } \\
\text { treatment }\end{array}$ & $\begin{array}{l}\text { Mediating PSCs phenotypical switch and stromal } \\
\text { remodeling }[58] \\
\text {.Enhancing PDAC treatment }[58,108]\end{array}$ \\
\hline Growth factors & $\begin{array}{l}\text { hepatocyte growth factor } \\
\text { (HGF), Connective tissue } \\
\text { growth factor (CCN2), others }\end{array}$ & $\begin{array}{l}\text { "Multifunctional messengers" among } \\
\text { all components in TME }\end{array}$ & $\begin{array}{l}\text { Promoting growth, invasion, migration, and } \\
\text { chemotherapy resistance of PDA cells [34] } \\
\text {-Modulator of metabolic crosstalk between tumor } \\
\text { cells and stromal components [73] } \\
\text {.PSCs fibrogenic signaling [73] }\end{array}$ \\
\hline $\begin{array}{l}\text { Other signaling } \\
\text { pathways }\end{array}$ & $\begin{array}{l}\text { HIF-1a, ROS, NF-KB, TGF- } \beta / \\
\text { Smad, VEGF, PDGF, GM-CSF } \\
\text { and so on }\end{array}$ & $\begin{array}{l}\text { Commonly present in numerous } \\
\text { malignancies }\end{array}$ & $\begin{array}{l}\text { TME remodeling; promoting proliferation, } \\
\text { invasion, migration, chemotherapy resistance, } \\
\text { angiogenesis, immune evasion and other } \\
\text { behaviors of PDA cells }[75-80]\end{array}$ \\
\hline
\end{tabular}

Notes: PSCs-related paracrine signaling pathways have been depicted above, including their biological roles, functional molecules and influences on PDAC behaviors

interactions (Table 2), including $\mathrm{Ca}^{2+}$ signaling, VEGF, PDGF, Toll-like receptors (TLRs) signaling, HIF- $1 \alpha$ signaling, TGF- $\beta /$ Smad pathways, tumor necrosis factor- $\alpha$ (TNF- $\alpha$ ), monocyte chemoattractant protein-1 (MCP-1), and periostin, which exert various influences on PDAC pathology [15, 34, 65-83] (Table 2). Additionally, the involvements of miRNAs and exosomes have recently being reported [84]. For example, PSCs-induced miR-210, miR-199 upregulation plays an important role in PDA cells EMT and migration [85-87], and PSCs-derived exosomal miR-21 and CCN2 partially drive PSCs fibrotic signaling [73]. However, further relevant mechanisms still need to be uncovered.

New perspectives on PSCs-mediated molecular mechanisms that contribute to metastasis and chemoresistance of PDAC During dissemination from a primary tumor, TME plays a critical role in determining PDAC invasion and metastasis, regardless of "collective migration" or proteasedependent/independent single tumor cell invasion [88]. In particular, the plasticity of PDA cells invasion is further affected by interactions within the tumor stroma, where neighboring non-tumor cells contribute to regulating invasion or distant metastasis by a variety of mechanisms. Another troublesome problem is therapeutic resistance, which is a major contributor to the poor clinical outcomes of PDAC [89]. PSCs can exert multiple functions that are responsible for PDAC invasion, metastasis and drug resistance, such as ECM remodeling, paracrine signaling circuits, immune regulation, metabolic alterations, local proteolytic degradation, and angiogenesis $[8,40]$. The updated studies focused on the PSCs' new contributions to the biological behaviors of PDAC are as following (Fig. 2):

(1) 'Solid stress' and therapeutic resistance: Elevated tissue stiffening has become a widely accepted and passionately studied biomechanical property of fibrogenic tumors [90]. The item 'solid stress' refers to the physical forces caused by solid and elastic elements of the extracellular matrix and cells [90, 91]. Recently, increasing evidence suggested that the existence of solid stress is strongly linked to several hallmarks of tumor, such as proliferation, metabolism and metastasis [91-93]. In PDAC, tumor interstitial matrix (e.g. collagen, HA) and related stromal cells, such as CAFs and PSCs, mainly contribute to the solid stress. The increased solid stress is largely responsible for intratumoral vessels compression, lower perfusion and local hypoxia [24, 94]. More importantly, growth-induced solid stress tightly correlates with PDAC therapeutic resistance, and strategies designed to alleviate solid stress have the potential to improve PDAC treatment [94, 95]. It's implied that fibrotic and hypovascular stroma reduce drugs delivery via collapsed intratumoral blood vessels, and high interstitial fluid pressure (IFP) [96, 97](Fig. 2). Continuous activation of PSCs (or CAFs) produce various ECM proteins such as HIF-1 $\alpha$, collagen1 (COL1), SHH and PSCsderived periostin, which promote tumor progression, drug irresponsiveness, and contributes to tumor-supportive microenvironment and radio-/chemoresistance [24, 67, 98, 99]. Moreover, a recent study indicated that the amplified crosstalk among cancer-associated adipocytes (CAAs), tumor-associated neutrophils (TANs), and PSCs that occurs in PDAC related obesity leads to an aggravation of solid stress, increased tumor progression and reduced chemotherapy response [95]. CAAs generates an inflammatory and fibrotic TME of PDAC. Abundant adipocyte-secreted interlukin-1 $\beta$ (IL-1 $\beta$ ) mediates obesityinduced TANs infiltration and PSCs activation in PDAC. Interactions between PSCs and TANs exacerbates desmoplasia in PDAC via angiotensin-II type-1 receptor (AT1) signaling, which largely hinders the delivery and efficacy of chemotherapy [95].

Apart from the theory of solid stress, another novel mechanism of PSCs-mediated therapeutic resistance has been recognizing. Transforming growth factor- $\beta$ (TGF- $\beta$ ) mediates PSCs-expressed cysteine-rich angiogenic inducer61 (CYR61), a matricellular protein that negatively regulates nucleoside transporters hENT1 and hCNT3, which are responsible for cellular uptake of gemcitabine, largely reducing chemotherapy responses [100] (Fig. 2). 


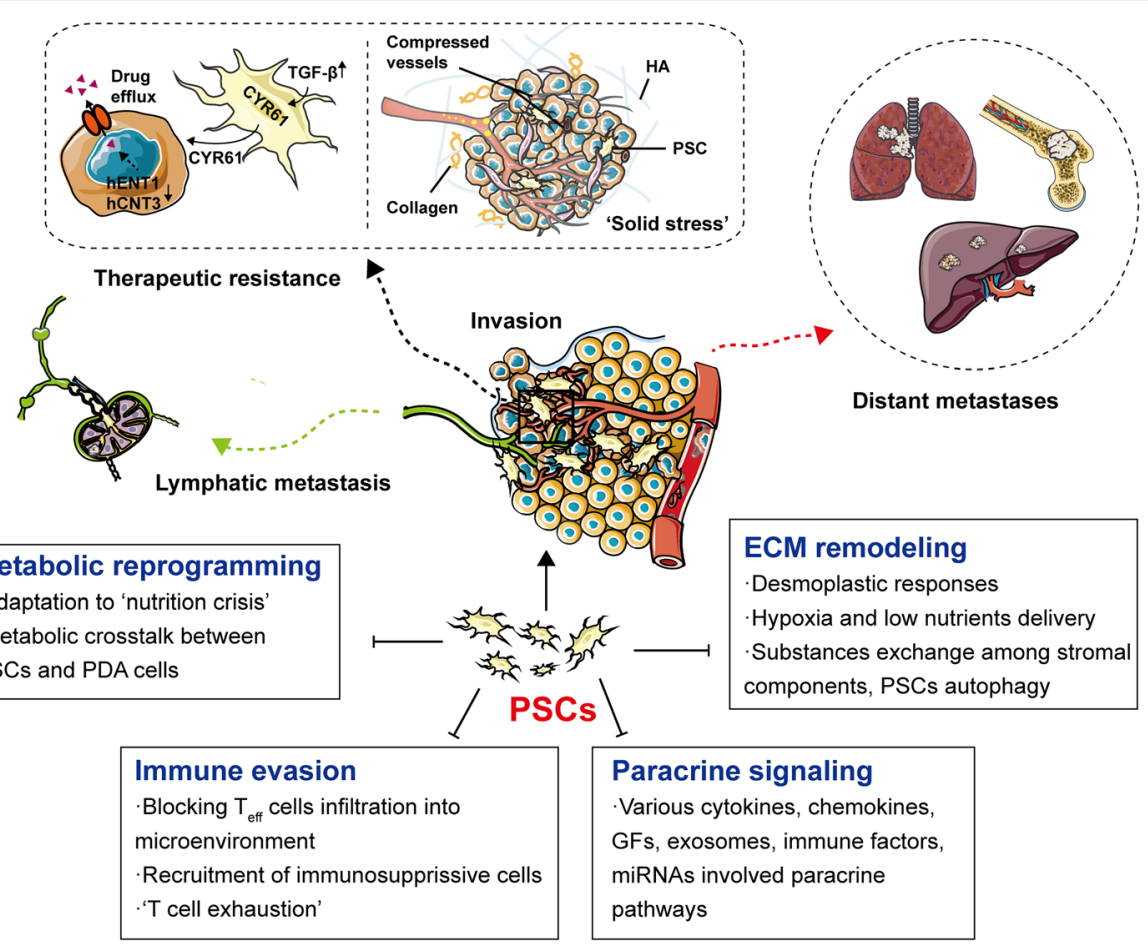

Fig. 2 PSCs mediate invasion, metastasis, therapeutic resistance of PDAC. Multiple factors are involved in, such as immune evasion, metabolic reprogramming, ECM remodeling, various paracrine signaling and so forth

(2) Newly identified PSCs-expressed miRNAs and PDAC progression: miRNAs have become a hot spot for cancer research [101]. In PDAC, some new investigations highlighted the roles of PSC-expressing miRNAs in controlling the myofibroblast phenotype of PSCs and their influences on migration and proliferation of tumor cells. For example, miR-210 was reported to regulate the interactions between PSCs and PDA cells via ERK and Akt pathways [85]. Moreover, recent studies validated that miR-199a and miR-214 are upregulated in patient-derived pancreatic PSCs, and targeting them caused the dedifferentiation of aPSCs and inhibited tumor-promoting paracrine effects [86].

(3) Autophagy in aPSCs: A potential target for PDAC: Besides revealed involvement of PSCs in tumor invasion and metastasis (e.g. MMPs activities, EMT, angiogenesis, signaling pathways and so on), new in vivo findings suggested that autophagy in PSCs, which is induced by environmental stress and PDA cells-stroma interactions, is strongly associated with tumor $\mathrm{T}$ category histologic grade, peritoneal dissemination, perivascular invasion and lymph node metastasis [102]. This novel discovery might be a goal of therapeutic interest, and predict the hypothesis that targeting autophagy could be a promising candidate for treatment strategies in PDAC. Coenzyme Q10 (CoQ10), commonly known as ubiquinone, has been suggested to inhibit the activation of aPSCs by suppressing the autophagy through activating
PI3K/AKT/mTOR signaling pathway [103], which may be explored to treat PSC-related pathologies and to develop anti-fibrotic approaches. Another therapeutic agent, Tocotrienols, selectively trigger aPSCs apoptosis and autophagic death by targeting the mitochondrial permeability transition pore [104]. It also unveils another potential approach to ameliorate the fibrogenesis in PDAC.

\section{aPSCs in PDAC metabolic reprogramming}

The TME of PDAC is the major source of both interstitial pressure and oxidative stress [105]. High concentration of the PSCs-derived matrix including hyaluronic acid (HA), collagen and glycosaminoglycan, contributes to the dense fibrotic stroma and subsequently leads to intense pressure in TME [106]. As a result, elevated stromal pressure causes vascular collapse, tumor tissue hypo-perfusion, and a lack of oxygen and nutrient delivery $[105,107,108]$. The environmental stress imposes "energy crisis" to cancer cells. Despite diverse mechanisms promoting extracellular glucose acquisition via the Warburg or the reverse Warburg effect in cancer cells (e.g. HIF- $1 \alpha$ signaling, over-expression of aerobic glycolytic enzymes like NF-kB, MCTs, PKM1/2) [108-111], obviously, enhanced glucose metabolism cannot compensate for energetic and biosynthetic shortfall completely. To sustain macromolecular biosynthesis and better tumor survival, metabolic rewiring among cancer cells and stromal components enables 
access to recycling nutritional substrates and alternative fuel sources for growth [112, 113]. More importantly, accumulating studies suggest that PSCs can strikingly reprogram metabolic machinery for PDAC, especially the metabolic crosstalk between PSCs and PDA cells, therefore facilitating PDAC progression and invasiveness under nutrient-limiting conditions $[114,115]$. In general, understanding more details about metabolic reciprocation between epithelial cancer cells and aPSCs seems to be crucial. It's recognized that besides environmental stresses, metabolic interplay between PDA cells and PSCs is the consequence of genetic mutations combined with comprehensive paracrine signaling regulations $[108,115,116]$ (Fig. 3).

Multiple genes (e.g. TP53, Myc, Smad4, CDKN2A) can drive PDAC metabolic reprogramming to meet the demands of tumor-relevant anabolic processes under sterile conditions [108, 117]. Among these, oncogenic KRAS mutation signaling has been recently shown to play a predominant role in multiple aspects of PDAC metabolism, including adaptive metabolic responses and cancer cells-PSCs mutualism [115, 118]. More evidence has emerged that the KRAS mutation not only enhances glucose uptake, but also activates expression of several key enzymes in aerobic glycolysis (the Warburg effect). Furthermore, KRAS-driven glutamine (Gln) metabolism becomes a major source of carbon and nitrogen for cancer cells proliferation [119]. It's demonstrated that oncogenic KRAS signaling mainly drives Gln conversion into aspartate for further energy generation and anabolism by activating the GOT2/GOT1/ME1 pathway, while at the same time, initiating glutathione (GSH) and NADPH biosynthesis, and inhibiting Nrf2/ME1/ROS activities to sustain cellular redox balance and enhance cytoprotection of cancer cells [113, 115, 120].

Recently, it's become increasingly apparent that the tumor cell KRAS mutation manipulates signaling within both PDA cells and adjacent PSCs, and influences PSCstumoral metabolic interactions. KRAS rapidly promotes sonic hedgehog ( $\mathrm{SHH}$ ) secretion from PDA cells, which activates PSCs to induce widespread events such as overexpression of IGF1, GAS6, GM-CSF and other cytokines. This results in PSCs reciprocally sending a feedback signaling to PDA cells via IGF1R/AXL axis, activating downstream PI3K-Akt phosphorylation and increasing spare mitochondrial respiratory capacity in PDA cells [121], which elevates oxygen availability for PDA cells under hypoxia. Additionally, KRAS-mutant PDA cells upregulate macropinocytosis, an endocytosis-mediated bulk uptake, to import extracellular proteins, which is ultimately delivered to lysosomes for catabolism, fueling TCA cycle, essential amino acids recycling and supporting cell growth [122-124].

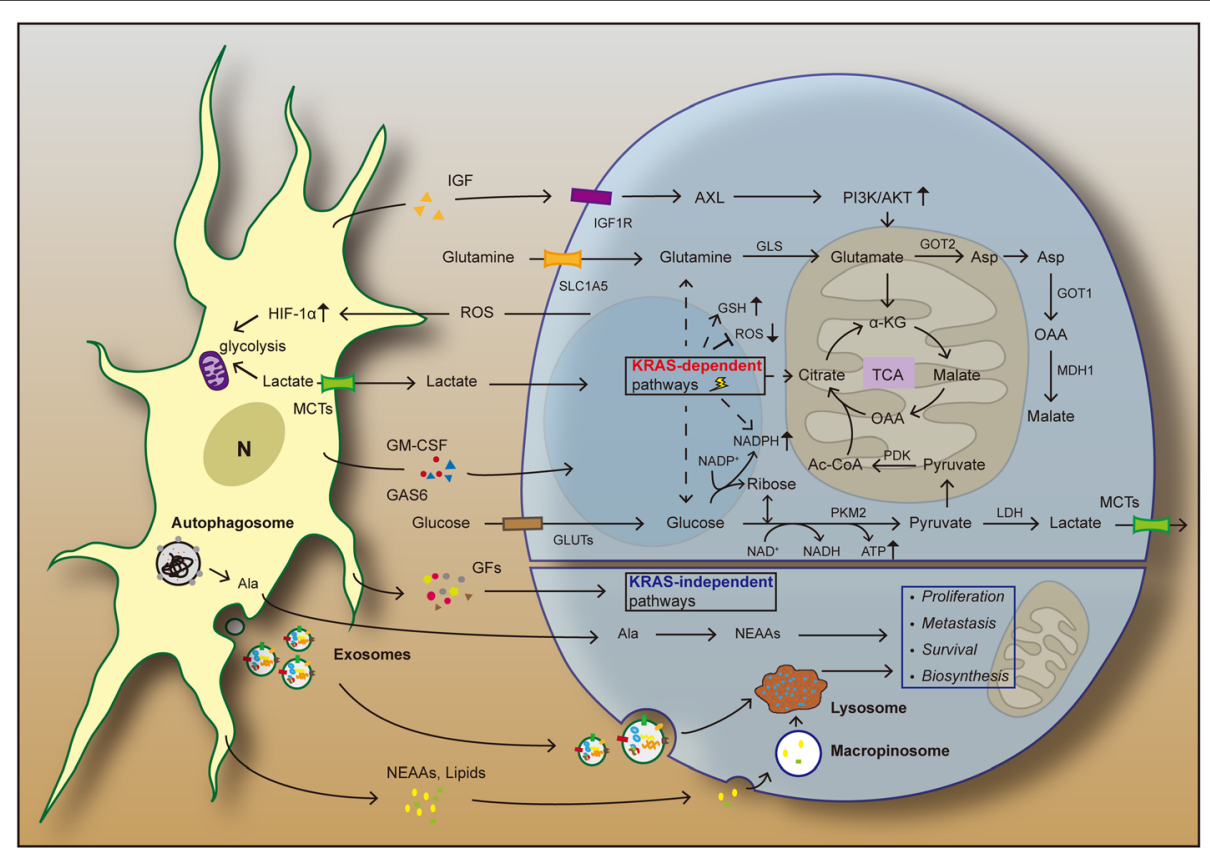

Fig. 3 PSCs in metabolic reprogramming. In KRAS-dependent pathways, diverse cytokines and signaling pathways mediate metabolic interactions between PSCs and PDA cells. KRAS-driven glutamine (GIn) metabolism becomes a major carbon source for tumor cells survival; PSCs-derived IGF elevates mitochondrial respiration in PDA cells via IGF1R/AXL axis; KRAS-mutant PDA cells can obtain extracellular proteins for supporting growth through upregulated macropinocytosis. PSCs-secreted non-essential amino acids (NEAAs), such as autophagy-induced Ala, can serve as an alternative energy source to fuel PDA cells. In KRAS-independent pathways, PSCs-derived growth factors (GFs) and exosomes play a pivotal role in mediating survival, proliferation, metastasis, biosynthesis of tumor cells 
More interestingly, PSCs-derived non-essential amino acids (NEAAs) also provide nutrients to feed PDA cells. Recent studies revealed that PDA cells increase autophagy in PSCs via unclear mechanisms [125], and then mediate PSCs secreting alanine (Ala) $[125,126]$. As a linkage of this cooperative metabolic relationship, PSCs-derived Ala is taken up by PDA cells and acts as an alternative carbon source to glucose/glutamine, shunts glucose to Ser/Gly biosynthesis, and supports lipid and NEAAs biosynthesis $[115,125]$.

In contrast to KRAS signaling related rewiring mentioned above, metabolic reprograming via KRAS-independent pathways has been identified [126]. GFs (e.g. connective tissue growth factor; CTGF and fibroblast growth factor-2; FGF2) and cytokines exchange between cancer cells and surrounding PSCs have been proved to be pivotal in metabolic crosstalk [126-128]. Furthermore, PSCs-derived exosomes contain various biomolecules, including mRNA, miRNA, intracellular metabolites (e.g. amino acids, acetate, stearate, palmitate, and lactate), which enter PDA cells, both fuel the tricarboxylic acid cycle (TCA cycle) and enhance tumor growth in a manner similar to macropinocytosis [84, 126, 128, 129].

Collectively, the description of these new metabolic crosstalk pathways further highlights that (1) PSCs play a key role in intra-tumoral metabolic networks, and (2) the PDA cells-PSCs metabolic "coupling" contributes significantly to PDAC development under nutrient-poor environment [115].

\section{PSCs-mediated immunosuppressive microenvironment in anticancer immunity}

Despite continuous progress in understanding the immune-dependent regulations of PDAC and the development of immunotherapies [130], therapeutic advances have been insufficient [131, 132]. Elucidating a method to enhance antitumor immunity and immunotherapy seems to be a challenge in PDAC treatment. Immune evasion and $\mathrm{T}$ cell dysfunction can be mediated by a variety of mechanisms, such as the immunosuppressive microenvironment in PDAC patients, which involves interactions among tumor cells, infiltrated immune cells and stromal components [108, 117], and makes a major hurdle for immune responses [133]. As a currently compelling role, PSCs display multiple effects on immunosuppressive regulation that makes PDAC therapeutics more difficult [134, 135] (Fig. 4).

First, $\alpha-\mathrm{SMA}^{+}$or $\mathrm{FAP}^{+}$PSCs play a pivotal role in TME remodeling. PSCs-mediated desmoplasia results in excess matrix deposition in TME, which has been postulated to limit $\mathrm{T}$ cell infiltration and function once recruited into tumor site [136, 137]. A striking cell-intrinsic pathway impacting cancer immunity is focal adhesion kinase (FAK), a tyrosine kinase that regulates $\mathrm{T}$ cell survival,

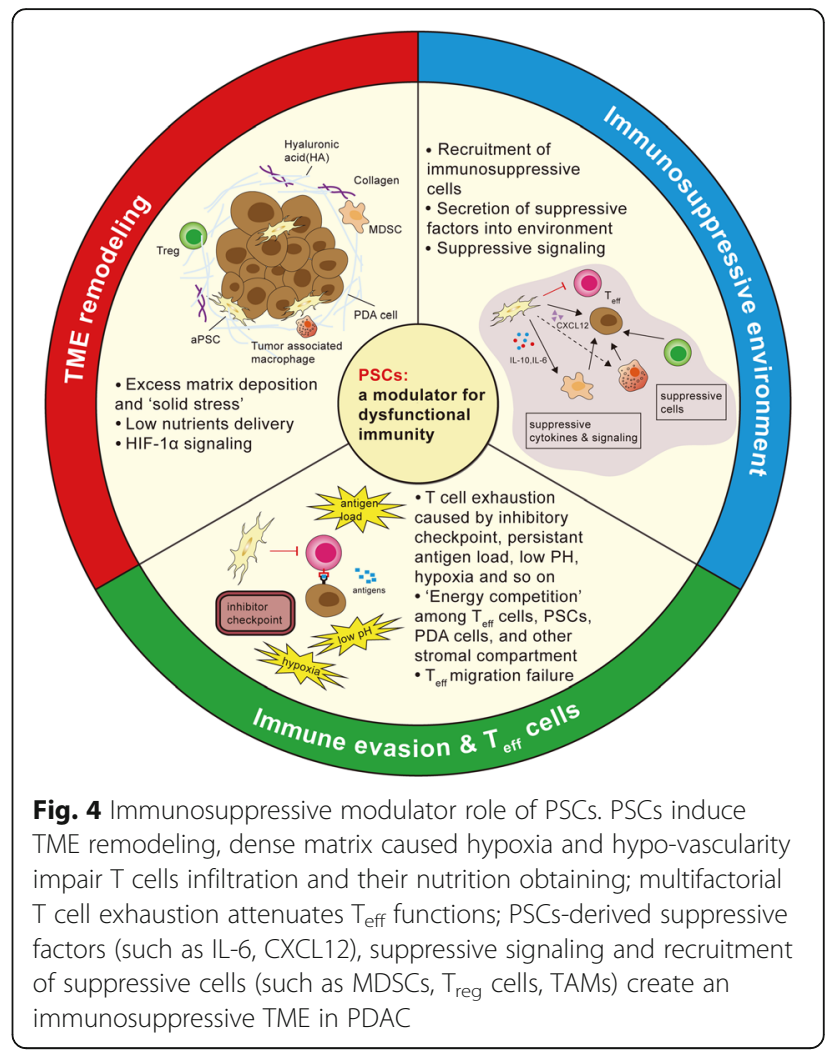

antigen sensitivity, cytokine production and migration [138]. FAK1 level is elevated in PDA cells and correlates with robust fibrosis and poor $\mathrm{CD}^{+} \mathrm{T}$ cell accumulation. The rigid ECM components secreted by PSCs, such as collagen or fibronectin, induce Rho-associated coiled-coil kinase-dependent activation of FAK1, greatly contributing to suppressed anticancer immunity [138].

Second, desmoplastic response creates hypoxic and avascular conditions, which imposes considerable energetic constraints on tumor cells, PSCs and immune cells [115]. As we mentioned above, PSCs constitute the major source of cancer-associated fibroblasts (CAFs) in PDAC. Paracrine signaling from neighbor PSCs (or CAFs) and CAFs-tumor cells interactions lead to metabolic reprogramming, by which cancer cells express more nutrients import molecules (e.g. GLUT1, MCTs, ASCT2, LATs) to obtain fuel sources for survival [139]. Elevated indoleamine-2,3 dioxygenase 1 (IDO1) and arginase (ARG1, ARG2) in metabolically altered CAFs may deplete tryptophan and arginine, which are crucial for $\mathrm{T}$ effector $\left(\mathrm{T}_{\text {eff }}\right)$ cells' proliferation and activation $[139,140]$. Meanwhile, confronted with "metabolic competition", lack of glucose impairs $\mathrm{T}$ cell's anti-tumor immunity and secretion of Interferon- $\gamma$ (IFN- $\gamma$ ) [141, 142], while low lipid support results in TNF receptor associated factor 6 (TRAF6) deficiency, which inhibits long-lasting memory $\mathrm{CD}^{+} \mathrm{T}$ cells formation [143]. 
Significantly, it has been commonly assumed that $\mathrm{T}$ cells in the context of established progressing cancer patients exhibit an exhausted status (termed as "T cell exhaustion") due to various factors, such as persistent tumor antigen load, inhibitory checkpoint signaling pathways (e.g. PD-1, LAG-3, CTLA-4), cell-intrinsic tolerance programs, and, more importantly, the complex immunosuppressive environment [144]. In PDAC, PSCs to a large extent mediate physiological changes in TME (e.g. hypoxia and low pH). HIF-1 $\alpha$ activation can suppress immunity or promote tumor evasion, however the underlying molecular mechanisms remain to be further identified $[145,146]$.

PSCs also secrete numerous soluble cytokines that contribute to "T cell exhaustion" and dysfunction. It's well evidenced that PSCs-derived CXCL12 (also named stromal-derived factor-1, SDF-1) can limit cytotoxic T cells trafficking, mediate macrophages' differentiation into a pro-tumor M2 phenotype (tumor-promiting), and recruit myeloid-derived suppressor cells (MDSCs), tumor-associated neutrophils to the tumor site [147]. At the same time, CXCL12/ SDF-1 bound to PDA cells can inhibit $T$ cell access to immune responses [148]. Recent clinical trials demonstrated that inhibiting CXCR4, a CXCL12 receptor, can dramatically promote T-cell accumulation and synergize with the checkpoint antagonist, $\alpha$-PD-L1, to cause cancer regression $[64,148]$.

Similarly, another versatile PSCs/MDSCs derived proinflammatory cytokine, interleukine-6 (IL-6), can suppress cytotoxic $\mathrm{T}$ lymphocyte $(\mathrm{CTL})$-driven antitumor immunity by multiple mechanisms, including impairing $\mathrm{T}_{\text {eff }}$ cells trans-endothelial migration, activation of $\mathrm{T}_{\text {reg }}$ cells Foxp3+ or tumor-associated macrophages (TAMs), and inducing imbalance of $\mathrm{T}_{\text {reg }} / \mathrm{T}_{\text {eff }}$ activities $[149,150]$. Moreover, large amounts of PSCs-derived suppressive cytokines such as IL10, TGF- $\beta$, VEGF, MCP-1, GM-CSF, $\mathrm{PGE}_{2}$, also contribute largely to immune evasion and anti-tumor hyporesponsiveness of PDAC [144, 151].

In short, with regard to the immunity regulation in PDAC, PSCs seem to be a powerful immunosuppressive modulator via numerous pathways. Targeting PSCs may pave a novel avenue for enhancing immunotherapies for PDAC.

\section{Conclusions}

PSCs surrounding tumor cells is an emerging stromal component that has been receiving huge attention recently. As a powerful tumor contributor, there is accumulating evidence supporting the multiple roles of PSCs in the establishment of TME, such as regulating environmental homeostasis and metabolic reprogramming, supporting tumor survival, immune evasion, invasion, distant metastasis and therapeutic resistance. The interplay between cancer cells and PSCs is increasingly recognized as a main driver for PDAC progression. Although development on basic studies and therapeutic strategies targeting PSCs have been revealing, more details on PSCs and PDAC treatment remains to be illustrated. It's promising that further understanding about PSCs will open new avenues for translational medicine and more meaningful clinical therapies for PDAC.

\section{Abbreviations}

Ala: Alanine; aPSCs: activated pancreatic stellate cells; ARG: Arginase; AT1: Angiotensin-II type-1 receptor; BMDCs: Bone marrow-derived cells; CAAs: Cancer-associated adipocytes; CAFs: Cancer-associated fibroblasts; COL1: Collagen 1; CoQ10: Coenzyme Q10; CTGF: Connective tissue growth factor; CTL: Cytotoxic T lymphocyte; CTLA-4: Cytotoxic T lymphocyteassociated antigen-4; CXCL12: C-X-C motif chemokine 12; CXCR4: C-X-C chemokine receptor type 4; CYR61: Cysteine-rich angiogenic inducer61; ECM: Extracellular matrix; ERK: Extracellular signal-regulated kinase; FAK: Focal adhesion kinase; FAP-a: Fibroblast activation protein-a; FGF2: Fibroblast growth factor-2; FSP-1: Fibroblast-specific protein-1; GFAP: Glial fibrillary acidic protein; GFs: Growth factors; GIn: Glutamine; Gly: Glycine; GOT1: Aspartate aminotransferase 1; GOT2: Aspartate aminotransferase 2; GSH: Glutathione; HA: Hyaluronic acid; HH: Hedgehog; HIF-1a: Hypoxia inducible factor 1a; HMGB1: High-mobility group box 1; IDO1: Indoleamine2,3 dioxygenase 1; IFN- $\gamma$ : Interferon- - ; IFP: Interstitial fluid pressure;

IGF1: Insulin-like growth factor 1; IL-1: Interleukin-1; IL10: Interleukin-10; IL6: Interleukin-6; JAK: Janus kinases; LAG-3: Lymphocyte-activation gene 3; MCP-1: Monocyte chemoattractant protein-1; MCTs: Monocarboxylate transporters; MDSCs: Myeloid-derived suppressor cells; ME1: Malic enzyme 1; miRNAs: microRNAs; MMPs: Matrix metalloproteinases; NADPH: Hicotinamide adenine dinucleotide phosphate; NEAAs: Non-essential amino acids; NFkB: Nuclear factor-KB; Nrf2: Nuclear factor erythroid 2; PD-1: Programmed cell death protein 1; PDAC: Pancreatic ductal adenocarcinoma; PDGF: Plateletderived growth factor; PI3K: Phosphatidylinositol 3 kinase; PKM1/2: Pyruvate kinase M 1 and 2; PNI: Perineural invasion; PSCs: Pancreatic stellate cells; PanIN: Pancreatic intraepithelial neoplasia; qPSCs: quiescent pancreatic stellate cells; ROCK2: Rho-associated protein kinase2; ROS: Reactive oxygen species; SDF-1: Stromal-derived factor-1; Ser: Serine; SHH: Sonic hedgehog; SMO: Smoothened; SOCS3: Suppressor of cytokine signaling 3; STAT: Signal transducer and activator of transcription; TANs: Tumor-associated neutrophils; $T_{\text {eff: }} T$ effector cells; TGF- $\beta$ : Transforming growth factor- $\beta$; TIMPs: Tissue inhibitors of metalloproteinases; TLRs: Toll-like receptors; TME: Tumor microenvironment; TNF-a: Tumor necrosis factor-a; TRAF6: TNF receptor associated factor 6; Treg: Regulatory T cell; VDR: Vitamin D Receptor; VEGF: Vascular endothelial growth factor; VEGFR: Vascular endothelial growth factor receptor; a-SMA:

a-smooth muscle actin

Acknowledgements

The authors thank Dr. Xingyu Li for assisting in drafting the tables.

\section{Funding}

This study was supported by grants from the National Natural Science Foundation of China (No. 81172470, 81070362, 81372629 \& 81772627), and two key projects from the Nature Science Foundation of Hunan Province (No. 2015JC3021 \& No. 2016JC2037).

Availability of data and materials Not applicable.

\section{Authors' contributions}

YF, SL, SZ and HS designed and drafted the manuscript; YF, SZ and HS wrote figure legends and revised the article; SL drew the figures. All authors read and approved the final manuscript.

Ethics approval and consent to participate Not applicable. 


\section{Consent for publication}

Not applicable.

\section{Competing interests}

The authors declare that they have no competing interests.

\section{Publisher's Note}

Springer Nature remains neutral with regard to jurisdictional claims in published maps and institutional affiliations.

\section{Author details}

'Department of Oncology, Xiangya Hospital, Central South University, Changsha, Hunan 410008, China. Institute of Medical Sciences, Xiangya Hospital, Central South University, Changsha, Hunan 410008, China. ${ }^{3}$ Key Laboratory for Molecular Radiation Oncology of Hunan Province, Xiangya Hospital, Central South University, Changsha, Hunan 410008, China.

Received: 28 November 2017 Accepted: 12 February 2018 Published online: 19 February 2018

\section{References}

1. Ryan DP, Hong TS, Bardeesy N. Pancreatic adenocarcinoma. N Engl J Med. 2014;371:2140-1.

2. Muckenhuber A, Berger AK, Schlitter AM, Steiger K, Konukiewitz B, Trumpp A, Eils R, Werner J, Friess H, Esposito I, et al: Pancreatic Ductal Adenocarcinoma Subtyping using the Biomarkers Hepatocyte Nuclear Factor-1A and Cytokeratin81 Correlates with Outcome and Treatment Response. Clin Cancer Res 2017. https://oi.org/10.1158/1078-0432.CCR-17-2180. [Epub ahead of print]

3. Siegel RL, Miller KD, Jemal A. Cancer Statistics, 2017. CA Cancer J Clin. 2017; 67:7-30.

4. Blair $A B$, Zheng L. Rational combinations of immunotherapy for pancreatic ductal adenocarcinoma. Chin Clin Oncol. 2017;6:31.

5. Chronopoulos A, Robinson B, Sarper M, Cortes E, Auernheimer V, Lachowski D, Attwood S, Garcia R, Ghassemi S, Fabry B, Del RHA. ATRA mechanically reprograms pancreatic stellate cells to suppress matrix remodelling and inhibit cancer cell invasion. Nat Commun. 2016;7:12630.

6. Ene-Obong A, Clear AJ, Watt J, Wang J, Fatah R, Riches JC, Marshall JF, ChinAleong J, Chelala C, Gribben JG, et al. Activated pancreatic stellate cells sequester CD8+ T cells to reduce their infiltration of the juxtatumoral compartment of pancreatic ductal adenocarcinoma. Gastroenterology. 2013;145:1121-32.

7. Berchtold S, Grunwald B, Kruger A, Reithmeier A, Hahl T, Cheng T, Feuchtinger A, Born D, Erkan M, Kleeff J, Esposito I. Collagen type V promotes the malignant phenotype of pancreatic ductal adenocarcinoma. Cancer Lett. 2015;356:721-32

8. Di Maggio F, Arumugam P, Delvecchio FR, Batista S, Lechertier T, HodivalaDilke K, Kocher HM. Pancreatic stellate cells regulate blood vessel density in the stroma of pancreatic ductal adenocarcinoma. Pancreatology. 2016;16: 995-1004.

9. Kadaba R, Birke H, Wang J, Hooper S, Andl CD, Di Maggio F, Soylu E, Ghallab M, Bor D, Froeling FE, et al. Imbalance of desmoplastic stromal cell numbers drives aggressive cancer processes. J Pathol. 2013;230:107-17.

10. Yeo D, Phillips P, Baldwin GS, He H, Nikfarjam M. Inhibition of group 1 p21activated kinases suppresses pancreatic stellate cell activation and increases survival of mice with pancreatic cancer. Int J Cancer. 2017;140:2101-11.

11. Apte MV, Haber PS, Applegate TL, Norton ID, McCaughan GW, Korsten MA, Pirola RC, Wilson JS. Periacinar stellate shaped cells in rat pancreas: identification, isolation, and culture. Gut. 1998;43:128-33.

12. Bachem MG, Schneider E, Gross H, Weidenbach H, Schmid RM, Menke A, Siech M, Beger H, Grunert A, Adler G. Identification, culture, and characterization of pancreatic stellate cells in rats and humans. Gastroenterology. 1998;115:421-32.

13. Xiao W, Jiang W, Shen J, Yin G, Fan Y, Wu D, Qiu L, Yu G, Xing M, Hu G, et al. Retinoic Acid Ameliorates Pancreatic Fibrosis and Inhibits the Activation of Pancreatic Stellate Cells in Mice with Experimental Chronic Pancreatitis via Suppressing the Wnt/beta-Catenin Signaling Pathway. Plos One. 2015;10: e141462.

14. Erkan M, Weis N, Pan Z, Schwager C, Samkharadze T, Jiang X, Wirkner U, Giese NA, Ansorge W, Debus J, et al. Organ-, inflammation- and cancer specific transcriptional fingerprints of pancreatic and hepatic stellate cells. Mol Cancer. 2010;9:88.
15. Roy I, Boyle KA, Vonderhaar EP, Zimmerman NP, Gorse E, Mackinnon AC, Hwang RF, Franco-Barraza J, Cukierman E, Tsai S, et al. Cancer cell chemokines direct chemotaxis of activated stellate cells in pancreatic ductal adenocarcinoma. Lab Invest. 2017:97:302-17.

16. Allam A, Thomsen AR, Gothwal M, Saha D, Maurer J, Brunner TB. Pancreatic stellate cells in pancreatic cancer: In focus. Pancreatology. 2017;17:514-22.

17. Sarper M, Cortes E, Lieberthal TJ, Del RHA. ATRA modulates mechanical activation of TGF-beta by pancreatic stellate cells. Sci Rep. 2016;6:27639.

18. Froeling FE, Feig C, Chelala C, Dobson R, Mein CE, Tuveson DA, Clevers H, Hart IR, Kocher HM. Retinoic acid-induced pancreatic stellate cell quiescence reduces paracrine Wnt-beta-catenin signaling to slow tumor progression. Gastroenterology. 2011;141:1486-97. 1491-1497

19. Zhan HX, Zhou B, Cheng YG, Xu JW, Wang L, Zhang GY, Hu SY. Crosstalk between stromal cells and cancer cells in pancreatic cancer: New insights into stromal biology. Cancer Lett. 2017:392:83-93.

20. Nielsen MF, Mortensen MB, Detlefsen S. Key players in pancreatic cancerstroma interaction: Cancer-associated fibroblasts, endothelial and inflammatory cells. World J Gastroenterol. 2016;22:2678-700.

21. Ohlund D, Handly-Santana A, Biffi G, Elyada E, Almeida AS, Ponz-Sarvise M, Corbo V, Oni TE, Hearn SA, Lee EJ, et al. Distinct populations of inflammatory fibroblasts and myofibroblasts in pancreatic cancer. J Exp Med. 2017;214:579-96.

22. Sada M, Ohuchida K, Horioka K, Okumura T, Moriyama T, Miyasaka Y, Ohtsuka T, Mizumoto K, Oda Y, Nakamura M. Hypoxic stellate cells of pancreatic cancer stroma regulate extracellular matrix fiber organization and cancer cell motility. Cancer Lett. 2016;372:210-8.

23. Laklai H, Miroshnikova YA, Pickup MW, Collisson EA, Kim GE, Barrett AS, Hill RC, Lakins JN, Schlaepfer DD, Mouw JK, et al. Genotype tunes pancreatic ductal adenocarcinoma tissue tension to induce matricellular fibrosis and tumor progression. Nat Med. 2016:22:497-505.

24. Olive KP, Jacobetz MA, Davidson CJ, Gopinathan A, Mclntyre D, Honess D, Madhu B, Goldgraben MA, Caldwell ME, Allard D, et al. Inhibition of Hedgehog signaling enhances delivery of chemotherapy in a mouse model of pancreatic cancer. Science. 2009;324:1457-61.

25. Jacobetz MA, Chan DS, Neesse A, Bapiro TE, Cook N, Frese KK, Feig C, Nakagawa T, Caldwell ME, Zecchini HI, et al. Hyaluronan impairs vascular function and drug delivery in a mouse model of pancreatic cancer. Gut. 2013:62:112-20.

26. Rhim AD, Oberstein PE, Thomas DH, Mirek ET, Palermo CF, Sastra SA, Dekleva EN, Saunders T, Becerra CP, Tattersall IW, et al. Stromal elements act to restrain, rather than support, pancreatic ductal adenocarcinoma. Cancer Cell. 2014;25:735-47.

27. Ozdemir BC, Pentcheva-Hoang T, Carstens JL, Zheng X, Wu CC, Simpson TR, Laklai H, Sugimoto H, Kahlert C, Novitskiy SV, et al. Depletion of carcinomaassociated fibroblasts and fibrosis induces immunosuppression and accelerates pancreas cancer with reduced survival. Cancer Cell. 2014;25:719-34.

28. Rath N, Morton JP, Julian L, Helbig L, Kadir S, McGhee EJ, Anderson KI, Kalna G, Mullin M, Pinho AV, et al. ROCK signaling promotes collagen remodeling to facilitate invasive pancreatic ductal adenocarcinoma tumor cell growth. Embo Mol Med. 2017;9:198-218.

29. Bever KM, Sugar EA, Bigelow E, Sharma R, Laheru D, Wolfgang $C L$, Jaffee EM, Anders $R A$, De Jesus-Acosta A, Zheng $L$. The prognostic value of stroma in pancreatic cancer in patients receiving adjuvant therapy. HPB (Oxford). 2015:17:292-8.

30. Zhang H, Wu H, Guan J, Wang L, Ren X, Shi X, Liang Z, Liu T. Paracrine SDF1alpha signaling mediates the effects of PSCS on GEM chemoresistance through an IL-6 autocrine loop in pancreatic cancer cells. Oncotarget. 2015;6:3085-97.

31. Vonlaufen A, Joshi S, Qu C, Phillips PA, Xu Z, Parker NR, Toi CS, Pirola RC, Wilson JS, Goldstein D, Apte MV. Pancreatic stellate cells: partners in crime with pancreatic cancer cells. Cancer Res. 2008;68:2085-93.

32. Whatcott CJ, Diep CH, Jiang P, Watanabe A, LoBello J, Sima C, Hostetter G, Shepard HM, Von Hoff DD, Han H. Desmoplasia in Primary Tumors and Metastatic Lesions of Pancreatic Cancer. Clin Cancer Res. 2015;21:3561-8.

33. Drifka CR, Eliceiri KW, Weber SM, Kao WJ. A bioengineered heterotypic stroma-cancer microenvironment model to study pancreatic ductal adenocarcinoma. Lab Chip. 2013;13:3965-75.

34. Yang XP, Liu SL, Xu JF, Cao SG, Li Y, Zhou YB. Pancreatic stellate cells increase pancreatic cancer cells invasion through the hepatocyte growth factor /c-Met/survivin regulated by P53/P21. Exp Cell Res. 2017; 357:79-87.

35. Neesse A, Algul H, Tuveson DA, Gress TM. Stromal biology and therapy in pancreatic cancer: a changing paradigm. Gut. 2015;64:1476-84. 
36. Kang Y, Roife D, Lee Y, Lv H, Suzuki R, Ling J, Rios PM, Li X, Dai B, Pratt M, et al. Transforming Growth Factor-beta Limits Secretion of Lumican by Activated Stellate Cells within Primary Pancreatic Adenocarcinoma Tumors. Clin Cancer Res. 2016;22:4934-46.

37. Lugea A, Waldron RT. Exosome-Mediated Intercellular Communication Between Stellate Cells and Cancer Cells in Pancreatic Ductal Adenocarcinoma. Pancreas. 2017;46:1-4.

38. Saha S, Xiong X, Chakraborty PK, Shameer K, Arvizo RR, Kudgus RA, Dwivedi SK, Hossen MN, Gillies EM, Robertson JD, et al. Gold Nanoparticle Reprograms Pancreatic Tumor Microenvironment and Inhibits Tumor Growth. Acs Nano. 2016;10:10636-51.

39. Yoshida N, Masamune A, Hamada S, Kikuta K, Takikawa T, Motoi F, Unno M, Shimosegawa T. Kindlin-2 in pancreatic stellate cells promotes the progression of pancreatic cancer. Cancer Lett. 2017;390:103-14.

40. Pang T, Wilson JS, Apte MV. Pancreatic stellate cells: what's new? Curr Opin Gastroenterol. 2017;33:366-73.

41. Nagathihalli NS, Castellanos JA, Shi C, Beesetty Y, Reyzer ML, Caprioli R, Chen X, Walsh AJ, Skala MC, Moses HL, Merchant NB. Signal Transducer and Activator of Transcription 3, Mediated Remodeling of the Tumor Microenvironment Results in Enhanced Tumor Drug Delivery in a Mouse Model of Pancreatic Cancer. Gastroenterology. 2015;149:1932-43.

42. Hamada S, Masamune A, Yoshida N, Takikawa T, Shimosegawa T. IL-6/STAT3 Plays a Regulatory Role in the Interaction Between Pancreatic Stellate Cells and Cancer Cells. Dig Dis Sci. 2016;61:1561-71.

43. Wormann SM, Song L, Ai J, Diakopoulos KN, Kurkowski MU, Gorgulu K, Ruess D, Campbell A, Doglioni C, Jodrell D, et al. Loss of P53 Function Activates JAK2-STAT3 Signaling to Promote Pancreatic Tumor Growth, Stroma Modification, and Gemcitabine Resistance in Mice and Is Associated With Patient Survival. Gastroenterology. 2016;151:180-93.

44. Lesina M, Kurkowski MU, Ludes K, Rose-John S, Treiber M, Kloppel G, Yoshimura A, Reindl W, Sipos B, Akira S, et al. Stat3/Socs3 activation by IL-6 transsignaling promotes progression of pancreatic intraepithelial neoplasia and development of pancreatic cancer. Cancer Cell. 2011;19: 456-69.

45. Corcoran RB, Contino G, Deshpande V, Tzatsos A, Conrad C, Benes CH, Levy DE, Settleman J, Engelman JA, Bardeesy N. STAT3 plays a critical role in KRAS-induced pancreatic tumorigenesis. Cancer Res. 2011;71:5020-9.

46. Long KB, Tooker G, Tooker E, Luque SL, Lee JW, Pan X, Beatty GL. IL6 Receptor Blockade Enhances Chemotherapy Efficacy in Pancreatic Ductal Adenocarcinoma. Mol Cancer Ther. 2017;16:1898-908.

47. Wu YS, Chung I, Wong WF, Masamune A, Sim MS, Looi CY. Paracrine IL-6 signaling mediates the effects of pancreatic stellate cells on epithelialmesenchymal transition via Stat3/Nrf2 pathway in pancreatic cancer cells. Biochim Biophys Acta. 2017;1861:296-306.

48. Huang L, Hu B, Ni J, Wu J, Jiang W, Chen C, Yang L, Zeng Y, Wan R, Hu G, Wang $X$. Transcriptional repression of SOCS3 mediated by IL-6/STAT3 signaling via DNMT1 promotes pancreatic cancer growth and metastasis. J Exp Clin Cancer Res. 2016;35:27.

49. Komar HM, Serpa G, Kerscher C, Schwoegl E, Mace TA, Jin M, Yang MC, Chen CS, Bloomston M, Ostrowski MC, et al. Inhibition of Jak/STAT signaling reduces the activation of pancreatic stellate cells in vitro and limits caerulein-induced chronic pancreatitis in vivo. Sci Rep. 2017;7:1787.

50. Hidalgo M, Maitra A. The hedgehog pathway and pancreatic cancer. N Engl J Med. 2009:361:2094-6.

51. Rucki AA, Foley K, Zhang P, Xiao Q, Kleponis J, Wu AA, Sharma R, Mo G, Liu A, Van Eyk J, et al. Heterogeneous Stromal Signaling within the Tumor Microenvironment Controls the Metastasis of Pancreatic Cancer. Cancer Res. 2017;77:41-52.

52. Cox TR, Erler JT. Fibrosis and Cancer: Partners in Crime or Opposing Forces? Trends Cancer. 2016:2:279-82.

53. Damhofer H, Medema JP, Veenstra VL, Badea L, Popescu I, Roelink H, Bijlsma MF. Assessment of the stromal contribution to Sonic Hedgehog-dependent pancreatic adenocarcinoma. Mol Oncol. 2013;7:1031-42.

54. Li X, Wang Z, Ma Q, Xu Q, Liu H, Duan W, Lei J, Ma J, Wang X, Lv S, et al. Sonic hedgehog paracrine signaling activates stromal cells to promote perineural invasion in pancreatic cancer. Clin Cancer Res. 2014; 20:4326-38

55. Mathew E, Zhang Y, Holtz AM, Kane KT, Song JY, Allen BL, Pasca DMM. Dosage-dependent regulation of pancreatic cancer growth and angiogenesis by hedgehog signaling. Cell Rep. 2014;9:484-94.

56. Diaz L, Diaz-Munoz M, Garcia-Gaytan AC, Mendez I. Mechanistic Effects of Calcitriol in Cancer Biology. Nutrients. 2015;7:5020-50.
57. Wolpin BM, Ng K, Bao Y, Kraft P, Stampfer MJ, Michaud DS, Ma J, Buring JE, Sesso HD, Lee IM, et al. Plasma 25-hydroxyvitamin D and risk of pancreatic cancer. Cancer Epidemiol Biomarkers Prev. 2012;21:82-91.

58. Sherman MH, Yu RT, Engle DD, Ding N, Atkins AR, Tiriac H, Collisson EA, Connor F, Van Dyke T, Kozlov S, et al. Vitamin D receptor-mediated stromal reprogramming suppresses pancreatitis and enhances pancreatic cancer therapy. Cell. 2014;159:80-93.

59. Shakir M, Tang D, Zeh HJ, Tang SW, Anderson CJ, Bahary N, Lotze MT. The chemokine receptors CXCR4/CXCR7 and their primary heterodimeric ligands CXCL12 and CXCL12/high mobility group box 1 in pancreatic cancer growth and development: finding flow. Pancreas. 2015;44:528-34.

60. Morimoto M, Matsuo Y, Koide S, Tsuboi K, Shamoto T, Sato T, Saito K, Takahashi H, Takeyama H. Enhancement of the CXCL12/CXCR4 axis due to acquisition of gemcitabine resistance in pancreatic cancer: effect of CXCR4 antagonists. Bmc Cancer. 2016;16:305.

61. Li X, Ma Q, Xu Q, Liu H, Lei J, Duan W, Bhat K, Wang F, Wu E, Wang Z. SDF1/CXCR4 signaling induces pancreatic cancer cell invasion and epithelialmesenchymal transition in vitro through non-canonical activation of Hedgehog pathway. Cancer Lett. 2012;322:169-76.

62. Xu Q, Wang Z, Chen X, Duan W, Lei J, Zong L, Li X, Sheng L, Ma J, Han L, et al. Stromal-derived factor-1alpha/CXCL12-CXCR4 chemotactic pathway promotes perineural invasion in pancreatic cancer. Oncotarget. 2015;6:4717-32.

63. Sleightholm RL, Neilsen BK, Li J, Steele MM, Singh RK, Hollingsworth MA, Oupicky D. Emerging roles of the CXCL12/CXCR4 axis in pancreatic cancer progression and therapy. Pharmacol Ther. 2017;179:158-70.

64. Feig C, Jones JO, Kraman M, Wells RJ, Deonarine A, Chan DS, Connell CM, Roberts EW, Zhao Q, Caballero OL, et al. Targeting CXCL12 from FAPexpressing carcinoma-associated fibroblasts synergizes with anti-PD-L1 immunotherapy in pancreatic cancer. Proc Natl Acad Sci U S A. 2013;110: 20212-7.

65. Shimizu K, Kobayashi M, Tahara J, Shiratori K. Cytokines and peroxisome proliferator-activated receptor gamma ligand regulate phagocytosis by pancreatic stellate cells. Gastroenterology. 2005;128:2105-18.

66. Kim N, Choi S, Lim C, Lee H, Oh J. Albumin mediates PPAR-gamma or C/ EBP-alpha-induced phenotypic changes in pancreatic stellate cells. Biochem Biophys Res Commun. 2010;391:640-4.

67. Erkan M, Kleeff J, Gorbachevski A, Reiser C, Mitkus T, Esposito I, Giese T, Buchler MW, Giese NA, Friess H. Periostin creates a tumor-supportive microenvironment in the pancreas by sustaining fibrogenic stellate cell activity. Gastroenterology. 2007;132:1447-64.

68. Kanno A, Satoh K, Masamune A, Hirota M, Kimura K, Umino J, Hamada S, Satoh A, Egawa S, Motoi F, et al. Periostin, secreted from stromal cells, has biphasic effect on cell migration and correlates with the epithelial to mesenchymal transition of human pancreatic cancer cells. Int J Cancer. 2008:122:2707-18.

69. Ben $\mathrm{QW}$, Jin $X \mathrm{~L}$, Liu J, Cai X, Yuan F, Yuan YZ. Periostin, a matrix specific protein, is associated with proliferation and invasion of pancreatic cancer. Oncol Rep. 2011;25:709-16.

70. Masamune A, Satoh M, Hirabayashi J, Kasai K, Satoh K, Shimosegawa T. Galectin-1 induces chemokine production and proliferation in pancreatic stellate cells. Am J Physiol Gastrointest Liver Physiol. 2006;290:G729-36.

71. Qian D, Lu Z, Xu Q, Wu P, Tian L, Zhao L, Cai B, Yin J, Wu Y, StaveleyO'Carroll KF, et al. Galectin-1-driven upregulation of SDF-1 in pancreatic stellate cells promotes pancreatic cancer metastasis. Cancer Lett. 2017; 397:43-51.

72. Tang D, Yuan Z, Xue X, Lu Z, Zhang Y, Wang H, Chen M, An Y, Wei J, Zhu Y, et al. High expression of Galectin-1 in pancreatic stellate cells plays a role in the development and maintenance of an immunosuppressive microenvironment in pancreatic cancer. Int J Cancer. 2012;130:2337-48.

73. Charrier A, Chen R, Chen L, Kemper S, Hattori T, Takigawa M, Brigstock DR. Connective tissue growth factor (CCN2) and microRNA-21 are components of a positive feedback loop in pancreatic stellate cells (PSC) during chronic pancreatitis and are exported in PSC-derived exosomes. J Cell Commun Signal. 2014;8:147-56.

74. Pitarresi JR, Liu X, Sharma SM, Cuitino MC, Kladney RD, Mace TA, Donohue S, Nayak SG, Qu C, Lee J, et al. Stromal ETS2 Regulates Chemokine Production and Immune Cell Recruitment during Acinar-to-Ductal Metaplasia. Neoplasia. 2016;18:541-52.

75. Coleman SJ, Chioni AM, Ghallab M, Anderson RK, Lemoine NR, Kocher HM, Grose RP. Nuclear translocation of FGFR1 and FGF2 in pancreatic stellate cells facilitates pancreatic cancer cell invasion. Embo Mol Med. 2014;6:467-81. 
76. Waghray M, Yalamanchili M, Dziubinski M, Zeinali M, Erkkinen M, Yang $H$, Schradle KA, Urs S, Pasca DMM, Welling TH, et al. GM-CSF Mediates Mesenchymal-Epithelial Cross-talk in Pancreatic Cancer. Cancer Discov. 2016:6:886-99.

77. Lu Y, Ji N, Wei W, Sun W, Gong X, Wang X. MiR-142 modulates human pancreatic cancer proliferation and invasion by targeting hypoxiainducible factor 1 (HIF-1alpha) in the tumor microenvironments. Biol Open. 2017;6:252-9.

78. Strell C, Norberg KJ, Mezheyeuski A, Schnittert J, Kuninty PR, Moro CF, Paulsson J, Schultz NA, Calatayud D, Lohr JM, et al. Stroma-regulated HMGA2 is an independent prognostic marker in PDAC and AAC. Br J Cancer. 2017;117:65-77.

79. Lei J, Huo X, Duan W, Xu Q, Li R, Ma J, Li X, Han L, Li W, Sun H, et al. alphaMangostin inhibits hypoxia-driven ROS-induced PSC activation and pancreatic cancer cell invasion. Cancer Lett. 2014;347:129-38.

80. Masamune A, Shimosegawa T. Signal transduction in pancreatic stellate cells. J Gastroenterol. 2009:44:249-60.

81. Ino K, Masuya M, Tawara I, Miyata E, Oda K, Nakamori Y, Suzuki K, Ohishi K, Katayama N. Monocytes infiltrate the pancreas via the MCP-1/CCR2 pathway and differentiate into stellate cells. Plos One. 2014;9:e84889.

82. Grimmig T, Moench R, Kreckel J, Haack S, Rueckert F, Rehder R, Tripathi S, Ribas C, Chandraker A, Germer CT, et al. Toll Like Receptor 2, 4, and 9 Signaling Promotes Autoregulative Tumor Cell Growth and VEGF/PDGF Expression in Human Pancreatic Cancer. Int J Mol Sci. 2016;17:2060.

83. Zambirinis CP, Levie E, Nguy S, Avanzi A, Barilla R, Xu Y, Seifert L, Daley D, Greco SH, Deutsch M, et al. TLR9 ligation in pancreatic stellate cells promotes tumorigenesis. J Exp Med. 2015;212:2077-94.

84. Takikawa T, Masamune A, Yoshida N, Hamada S, Kogure T, Shimosegawa T. Exosomes Derived From Pancreatic Stellate Cells: MicroRNA Signature and Effects on Pancreatic Cancer Cells. Pancreas. 2017:46:19-27.

85. Takikawa T, Masamune A, Hamada S, Nakano E, Yoshida N, Shimosegawa T. miR-210 regulates the interaction between pancreatic cancer cells and stellate cells. Biochem Biophys Res Commun. 2013;437:433-9.

86. Kuninty PR, Bojmar L, Tjomsland V, Larsson M, Storm G, Ostman A Sandstrom P, Prakash J. MicroRNA-199a and -214 as potential therapeutic targets in pancreatic stellate cells in pancreatic tumor. Oncotarget. 2016;7: 16396-408.

87. Han S, Gonzalo DH, Feely M, Delitto D, Behrns KE, Beveridge M, Zhang D, Thomas R, Trevino JG, Schmittgen TD, Hughes SJ. The pancreatic tumor microenvironment drives changes in miRNA expression that promote cytokine production and inhibit migration by the tumor associated stroma. Oncotarget. 2017:8:54054-67.

88. Javle M, Golan T, Maitra A. Changing the course of pancreatic cancer-Focus on recent translational advances. Cancer Treat Rev. 2016;44:17-25.

89. Dauer P, Nomura A, Saluja A, Banerjee S. Microenvironment in determining chemo-resistance in pancreatic cancer: Neighborhood matters. Pancreatology. 2017;17:7-12

90. Chauhan VP, Martin JD, Liu H, Lacorre DA, Jain SR, Kozin SV, Stylianopoulos T, Mousa AS, Han X, Adstamongkonkul P, et al. Angiotensin inhibition enhances drug delivery and potentiates chemotherapy by decompressing tumour blood vessels. Nat Commun. 2013:4:2516.

91. Tse JM, Cheng G, Tyrrell JA, Wilcox-Adelman SA, Boucher Y, Jain RK, Munn LL. Mechanical compression drives cancer cells toward invasive phenotype. Proc Natl Acad Sci U S A. 2012;109:911-6.

92. Chaudhuri O, Koshy ST, Branco DCC, Shin JW, Verbeke CS, Allison KH, Mooney DJ. Extracellular matrix stiffness and composition jointly regulate the induction of malignant phenotypes in mammary epithelium. Nat Mater. 2014;13:970-8

93. Tung JC, Barnes JM, Desai SR, Sistrunk C, Conklin MW, Schedin P, Eliceiri KW, Keely PJ, Seewaldt VL, Weaver VM. Tumor mechanics and metabolic dysfunction. Free Radic Biol Med. 2015;79:269-80.

94. Stylianopoulos T, Martin JD, Chauhan VP, Jain SR, Diop-Frimpong B, Bardeesy N, Smith BL, Ferrone CR, Hornicek FJ, Boucher Y, et al. Causes, consequences, and remedies for growth-induced solid stress in murine and human tumors. Proc Natl Acad Sci U S A. 2012;109:15101-8.

95. Incio J, Liu H, Suboj P, Chin SM, Chen IX, Pinter M, Ng MR, Nia HT, Grahovac J, Kao S, et al. Obesity-Induced Inflammation and Desmoplasia Promote Pancreatic Cancer Progression and Resistance to Chemotherapy. Cancer Discov. 2016;6:852-69.

96. Manji GA, Olive KP, Saenger YM, Oberstein P. Current and Emerging Therapies in Metastatic Pancreatic Cancer. Clin Cancer Res. 2017;23:1670-8.
97. McCarroll JA, Naim S, Sharbeen G, Russia N, Lee J, Kavallaris M, Goldstein D, Phillips PA. Role of pancreatic stellate cells in chemoresistance in pancreatic cancer. Front Physiol. 2014;5:141.

98. Heinemann V, Reni M, Ychou M, Richel DJ, Macarulla T, Ducreux M. Tumourstroma interactions in pancreatic ductal adenocarcinoma: rationale and current evidence for new therapeutic strategies. Cancer Treat Rev. 2014;40:118-28.

99. Liu Y, Li F, Gao F, Xing L, Qin P, Liang X, Zhang J, Qiao X, Lin L, Zhao Q, Du L. Periostin promotes tumor angiogenesis in pancreatic cancer via ErkNEGF signaling. Oncotarget. 2016;7:40148-59.

100. Hesler RA, Huang JJ, Starr MD, Treboschi VM, Bernanke AG, Nixon AB, McCall SJ, White RR, Blobe GC. TGF-beta-induced stromal CYR61 promotes resistance to gemcitabine in pancreatic ductal adenocarcinoma through downregulation of the nucleoside transporters hENT1 and hCNT3. Carcinogenesis. 2016;37:1041-51.

101. Schoepp M, Ströse AJ, Haier J. Dysregulation of miRNA Expression in Cancer Associated Fibroblasts (CAFs) and Its Consequences on the Tumor Microenvironment. Cancers. 2017; 9(6):54. http://www.mdpi.com/2072-6694/ 9/6/54.

102. Endo S, Nakata K, Ohuchida K, Takesue S, Nakayama H, Abe T, Koikawa K, Okumura T, Sada M, Horioka K, et al. Autophagy Is Required for Activation of Pancreatic Stellate Cells, Associated With Pancreatic Cancer Progression and Promotes Growth of Pancreatic Tumors in Mice. Gastroenterology. 2017;152:1492-506.

103. Xue R, Yang J, Wu J, Meng Q, Hao J. Coenzyme Q10 inhibits the activation of pancreatic stellate cells through PI3K/AKT/mTOR signaling pathway. Oncotarget. 2017:8:92300-11.

104. Rickmann M, Vaquero EC, Malagelada JR, Molero X. Tocotrienols induce apoptosis and autophagy in rat pancreatic stellate cells through the mitochondrial death pathway. Gastroenterology. 2007;132:2518-32.

105. Carapuca EF, Gemenetzidis E, Feig C, Bapiro TE, Williams MD, Wilson AS, Delvecchio FR, Arumugam P, Grose RP, Lemoine NR, et al. Anti-stromal treatment together with chemotherapy targets multiple signalling pathways in pancreatic adenocarcinoma. J Pathol. 2016;239:286-96.

106. Provenzano PP, Cuevas C, Chang AE, Goel VK, Von Hoff DD, Hingorani SR. Enzymatic targeting of the stroma ablates physical barriers to treatment of pancreatic ductal adenocarcinoma. Cancer Cell. 2012;21:418-29.

107. Kamphorst JJ, Nofal M, Commisso C, Hackett SR, Lu W, Grabocka E, Vander HM, Miller G, Drebin JA, Bar-Sagi D, et al. Human pancreatic cancer tumors are nutrient poor and tumor cells actively scavenge extracellular protein. Cancer Res. 2015;75:544-53.

108. Perera RM, Bardeesy N. Pancreatic Cancer Metabolism: Breaking It Down to Build It Back Up. Cancer Discov. 2015;5:1247-61.

109. An MX, Li S, Yao HB, Li C, Wang JM, Sun J, Li XY, Meng XN, Wang HQ. BAG3 directly stabilizes Hexokinase $2 \mathrm{mRNA}$ and promotes aerobic glycolysis in pancreatic cancer cells. J Cell Biol. 2017;216

110. Baek G, Tse YF, Hu Z, Cox D, Buboltz N, McCue P, Yeo CJ, White MA, DeBerardinis RJ, Knudsen ES, Witkiewicz AK. MCT4 defines a glycolytic subtype of pancreatic cancer with poor prognosis and unique metabolic dependencies. Cell Rep. 2014;9:2233-49.

111. Fu Y, Liu S, Yin S, Niu W, Xiong W, Tan M, Li G, Zhou M. The reverse Warburg effect is likely to be an Achilles' heel of cancer that can be exploited for cancer therapy. Oncotarget. 2017:8:57813-25.

112. Gebregiworgis T, Purohit V, Shukla SK, Tadros S, Chaika NV, Abrego J, Mulder SE, Gunda V, Singh PK, Powers R. Glucose Limitation Alters Glutamine Metabolism in MUC1-Overexpressing Pancreatic Cancer Cells. J Proteome Res. 2017;16:3536-46.

113. Sherman MH, Yu RT, Tseng TW, Sousa CM, Liu S, Truitt ML, He N, Ding N, Liddle C, Atkins AR, et al. Stromal cues regulate the pancreatic cancer epigenome and metabolome. Proc Natl Acad Sci U S A. 2017;114:1129-34.

114. Wu YS, Looi CY, Subramaniam KS, Masamune A, Chung I. Soluble factors from stellate cells induce pancreatic cancer cell proliferation via Nrf2activated metabolic reprogramming and ROS detoxification. Oncotarget. 2016;7:36719-32.

115. Halbrook CJ, Lyssiotis CA. Employing Metabolism to Improve the Diagnosis and Treatment of Pancreatic Cancer. Cancer Cell. 2017;31:5-19.

116. Jiang SH, Li J, Dong FY, Yang JY, Liu DJ, Yang XM, Wang YH, Yang MW, Fu $X L$, Zhang XX, et al. Increased Serotonin Signaling Contributes to the Warburg Effect in Pancreatic Tumor Cells Under Metabolic Stress and Promotes Growth of Pancreatic Tumors in Mice. Gastroenterology. 2017;153:277-91.

117. Mayers JR, Torrence ME, Danai LV, Papagiannakopoulos T, Davidson SM, Bauer MR, Lau AN, Ji BW, Dixit PD, Hosios AM, et al. Tissue of origin dictates 
branched-chain amino acid metabolism in mutant Kras-driven cancers. Science. 2016;353:1161-5.

118. Dunne RF, Hezel AF. Genetics and Biology of Pancreatic Ductal Adenocarcinoma. Hematol Oncol Clin North Am. 2015;29:595-608.

119. Son J, Lyssiotis CA, Ying H, Wang X, Hua S, Ligorio M, Perera RM, Ferrone CR, Mullarky E, Shyh-Chang N, et al. Glutamine supports pancreatic cancer growth through a KRAS-regulated metabolic pathway. Nature. 2013;496:101-5.

120. Chakrabarti G, Moore ZR, Luo X, Ilcheva M, Ali A, Padanad M, Zhou Y, Xie Y, Burma S, Scaglioni PP, et al. Targeting glutamine metabolism sensitizes pancreatic cancer to PARP-driven metabolic catastrophe induced by $\beta$ lapachone. Cancer Metab. 2015;3:12.

121. Tape CJ, Ling S, Dimitriadi M, McMahon KM, Worboys JD, Leong HS, Norrie IC, Miller CJ, Poulogiannis G, Lauffenburger DA, Jorgensen C. Oncogenic KRAS Regulates Tumor Cell Signaling via Stromal Reciprocation. Cell. 2016;165:910-20.

122. Kamerkar S, LeBleu VS, Sugimoto H, Yang S, Ruivo CF, Melo SA, Lee JJ, Kalluri R. Exosomes facilitate therapeutic targeting of oncogenic KRAS in pancreatic cancer. Nature. 2017;546:498-503.

123. Davidson SM, Jonas O, Keibler MA, Hou HW, Luengo A, Mayers JR, Wyckoff J, Del RA, Whitman M, Chin CR, et al. Direct evidence for cancer-cell-autonomous extracellular protein catabolism in pancreatic tumors. Nat Med. 2017;23:235-41.

124. Commisso C, Davidson SM, Soydaner-Azeloglu RG, Parker SJ, Kamphorst JJ, Hackett S, Grabocka E, Nofal M, Drebin JA, Thompson CB, et al. Macropinocytosis of protein is an amino acid supply route in Rastransformed cells. Nature. 2013:497:633-7.

125. Sousa CM, Biancur DE, Wang X, Halbrook CJ, Sherman MH, Zhang L, Kremer D, Hwang RF, Witkiewicz AK, Ying $H$, et al. Pancreatic stellate cells support tumour metabolism through autophagic alanine secretion. Nature. 2016;536:479-83.

126. Zhao H, Yang L, Baddour J, Achreja A, Bernard V, Moss T, Marini JC, Tudawe T, Seviour EG, San LF, et al. Tumor microenvironment derived exosomes pleiotropically modulate cancer cell metabolism. Elife. 2016;5:e10250.

127. Charrier A, Brigstock DR. Regulation of pancreatic function by connective tissue growth factor (CTGF, CCN2). Cytokine Growth Factor Rev. 2013;24:59-68.

128. Eguchi D, Ikenaga N, Ohuchida K, Kozono S, Cui L, Fujiwara K, Fujino M, Ohtsuka T, Mizumoto K, Tanaka M. Hypoxia enhances the interaction between pancreatic stellate cells and cancer cells via increased secretion of connective tissue growth factor. J Surg Res. 2013;181:225-33.

129. Richards KE, Zeleniak AE, Fishel ML, Wu J, Littlepage LE, Hill R. Cancerassociated fibroblast exosomes regulate survival and proliferation of pancreatic cancer cells. Oncogene. 2017:36:1770-8.

130. Delitto D, Wallet SM, Hughes SJ. Targeting tumor tolerance: A new hope for pancreatic cancer therapy? Pharmacol Ther. 2016;166:9-29.

131. Stromnes IM, Hulbert A, Pierce RH, Greenberg PD, Hingorani SR. T-cell Localization, Activation, and Clonal Expansion in Human Pancreatic Ductal Adenocarcinoma. Cancer Immunol Res. 2017;5:978-91.

132. Johnson BR, Yarchoan M, Lee V, Laheru DA, Jaffee EM. Strategies for Increasing Pancreatic Tumor Immunogenicity. Clin Cancer Res. 2017;23:1656-69.

133. Reha J, Katz SC. Regional immunotherapy for liver and peritoneal metastases. J Surg Oncol. 2017;116:46-54.

134. Mace TA, Ameen Z, Collins A, Wojcik S, Mair M, Young GS, Fuchs JR, Eubank TD, Frankel WL, Bekaii-Saab T, et al. Pancreatic cancer-associated stellate cells promote differentiation of myeloid-derived suppressor cells in a STAT3dependent manner. Cancer Res. 2013;73:3007-18.

135. Schnurr M, Duewell P, Bauer C, Rothenfusser S, Lauber K, Endres S, Kobold S. Strategies to relieve immunosuppression in pancreatic cancer. Immunotherapy-Uk. 2015;7:363-76.

136. Fearon DT. The carcinoma-associated fibroblast expressing fibroblast activation protein and escape from immune surveillance. Cancer Immunol Res. 2014;2:187-93.

137. Stromnes IM, Schmitt TM, Hulbert A, Brockenbrough JS, Nguyen H, Cuevas C, Dotson AM, Tan X, Hotes JL, Greenberg PD, Hingorani SR. T Cells Engineered against a Native Antigen Can Surmount Immunologic and Physical Barriers to Treat Pancreatic Ductal Adenocarcinoma. Cancer Cell. 2015;28:638-52.

138. Jiang $H$, Hegde $S$, Knolhoff BL, Zhu Y, Herndon JM, Meyer MA, Nywening TM, Hawkins WG, Shapiro IM, Weaver DT, et al. Targeting focal adhesion kinase renders pancreatic cancers responsive to checkpoint immunotherapy. Nat Med. 2016;22:851-60.

139. Anderson KG, Stromnes IM, Greenberg PD. Obstacles Posed by the Tumor Microenvironment to T cell Activity: A Case for Synergistic Therapies. Cancer Cell. 2017;31:311-25.
140. Kalluri R. The biology and function of fibroblasts in cancer. Nat Rev Cancer. 2016;16:582-98.

141. Brand A, Singer K, Koehl GE, Kolitzus M, Schoenhammer G, Thiel A, Matos C, Bruss C, Klobuch S, Peter K, et al. LDHA-Associated Lactic Acid Production Blunts Tumor Immunosurveillance by T and NK Cells. Cell Metab. 2016;24: 657-71.

142. Chang CH, Qiu J, O'Sullivan D, Buck MD, Noguchi T, Curtis JD, Chen Q, Gindin M, Gubin MM, van der Windt GJ, et al. Metabolic Competition in the Tumor Microenvironment Is a Driver of Cancer Progression. Cell. 2015;162:1229-41.

143. Pearce EL, Walsh MC, Cejas PJ, Harms GM, Shen H, Wang LS, Jones RG, Choi $Y$. Enhancing CD8 T-cell memory by modulating fatty acid metabolism. Nature. 2009;460:103-7.

144. Schietinger A, Greenberg PD. Tolerance and exhaustion: defining mechanisms of T cell dysfunction. Trends Immunol. 2014;35:51-60.

145. Biswas SK. Metabolic Reprogramming of Immune Cells in Cancer Progression. Immunity. 2015;43:435-49.

146. Zhao T, Ren H, Jia L, Chen J, Xin W, Yan F, Li J, Wang X, Gao S, Qian D, et al. Inhibition of HIF-1alpha by PX-478 enhances the anti-tumor effect of gemcitabine by inducing immunogenic cell death in pancreatic ductal adenocarcinoma. Oncotarget. 2015;6:2250-62.

147. Pure E, Lo A. Can Targeting Stroma Pave the Way to Enhanced Antitumor Immunity and Immunotherapy of Solid Tumors? Cancer Immunol Res. 2016:4:269-78.

148. Liu Q, Liao Q, Zhao Y. Chemotherapy and tumor microenvironment of pancreatic cancer. Cancer Cell Int. 2017;17:68.

149. Tsukamoto $H$, Nishikata $R$, Senju S, Nishimura $Y$. Myeloid-derived suppressor cells attenuate $\mathrm{TH} 1$ development through IL-6 production to promote tumor progression. Cancer Immunol Res. 2013;1:64-76.

150. Mace TA, Shakya R, Pitarresi JR, Swanson B, McQuinn CW, Loftus S, Nordquist E, Cruz-Monserrate Z, Yu L, Young G, et al. IL-6 and PD-L1 antibody blockade combination therapy reduces tumour progression in murine models of pancreatic cancer. Gut. 2016; https://doi.org/10.1136/ gutjnl-2016-311585. [Epub ahead of print]

151. Mohammed S, Sukumaran S, Bajgain P, Watanabe N, Heslop HE, Rooney CM, Brenner MK, Fisher WE, Leen AM, Vera JF. Improving Chimeric Antigen Receptor-Modified T Cell Function by Reversing the Immunosuppressive Tumor Microenvironment of Pancreatic Cancer. Mol Ther. 2017;25:249-58.

\section{Submit your next manuscript to BioMed Central and we will help you at every step:}

- We accept pre-submission inquiries

- Our selector tool helps you to find the most relevant journal

- We provide round the clock customer support

- Convenient online submission

- Thorough peer review

- Inclusion in PubMed and all major indexing services

- Maximum visibility for your research

Submit your manuscript at www.biomedcentral.com/submit
Biomed Central 